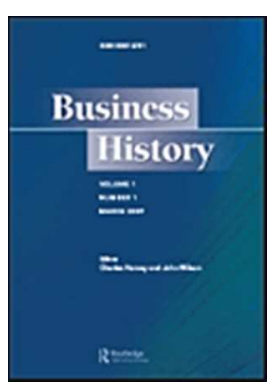

\title{
New Identities from Remnants of the Past: An Examination of the History of Beer Brewing in Ontario and the Recent Emergence of Craft Breweries
}

\begin{tabular}{|r|l|}
\hline Journal: & Business History \\
\hline Manuscript ID: & FBSH-2014-0084.R3 \\
\hline Manuscript Type: & Original Article \\
\hline Keywords: & Beer Brewing, institutional remnants, Collective Identity, Ontario, Canada \\
\hline \multicolumn{2}{|c}{} \\
\end{tabular}

SCHOLARONE $^{\text {m }}$

Manuscripts 


\begin{abstract}
We present an exploratory analysis of historical narratives and data covering 200 years of beer brewing in the Canadian province of Ontario. These data are used to illuminate the process of collective identity emergence in established organizational fields. We argue that established fields are typically littered with identity remnants from ancestral organizations and related institutional configurations that can facilitate the successful emergence of new collective identities. In our analysis we first show how multiple identity elements fell by the wayside as the beer brewing field matured and settled on a corporate path. We go on to detail how some of these identity elements were subsequently recovered during the recent decades which marked the successful emergence and proliferation of craft beer brewing. Our study has implications for research on collective identity and organizational legacy, and we stress the importance of taking a historical lens for understanding present day phenomena.
\end{abstract}

Key Words: Beer brewing, identity remnants, collective identity, industry evolution, Ontario, Canada 
What does it mean to be a commercial brewery? Is it about the spirit of entrepreneurship or a quest for global expansion? Does it mean to practice the age-old art and mystery of beer brewing? Is it about the utilization of modern science and technology to harness the power of a micro-organism or, perhaps it is a concern with providing merriment and entertainment for the imbibing public? If you are a brewer today, you might answer yes to all those possibilities and if you were able to ask a brewer dating back into history, you might hear quite a few more. The roles beer breweries have played over time and the identities they have acquired and promulgated in conjunction with those roles are arguably as varied as the styles of beer that are brewed the world over.

Questions of meaning and identity have been prominent in organizational studies for the past three decades in the search for answers about the symbolic and cultural value of business. ${ }^{1}$ The meaning of what an organization is matters not only to entice identification from its members, for whom it can provide direction, maintain cohesion, and instil a sense of organizational belonging. ${ }^{2}$ Meaning is also relevant to outside stakeholders because identity can reduce uncertainty and facilitate interactions with the organization. ${ }^{3}$

More recently, questions have been asked about the role and importance of collective identities - identities that characterize types of organizations rather than individual organizations - and how a collective identity of one or more organizational types in an organizational field or industry affects the strategic goals and actions of those organizations. ${ }^{4}$ Collective identities are important symbolic and cultural factors that influence whether an organization is seen as legitimate by its stakeholders ${ }^{5}$ and thus impact the collective performance and survival of organizational types. ${ }^{6}$

Despite the importance of collective identities to organizational survival and legitimacy, we know relatively little about how collective identities emerge. ${ }^{7}$ Moreover, we are still learning about how new organizations in established fields construct new collective identities and from 
where organizations obtain the symbolic and cultural resources to do so. ${ }^{8}$ A recent stream of research, inspired by institutional and ecological theories of organization ${ }^{9}$, suggests that a potent form of such resources may be found in the past. Specifically, this research has detailed how present day organizational dynamics continue to be influenced by ancestral organizations and associated institutional configurations even after they have disappeared. ${ }^{10}$

One central observation is that, in an ecological fashion, vanished organizations and associated institutional configurations leave behind institutional remnants that may provide vital resources for subsequent generations of organizations. These remnants have been shown to be a contributing factor in a number of organizational fields such as the Canadian forest industry, ${ }^{11}$ liquor retailing in Alberta, ${ }^{12}$ the US stock market, ${ }^{13}$ US cooperatives, ${ }^{14}$ and Chinese Corporate Social Responsibility. ${ }^{15}$ We use insights from this emerging genre of work to show how a new collective identity in an established organizational beer brewing field may have been built on the ashes of ancestral institutions.

Thus, our general research question is: how do organizations in established industries develop a collective identity? To this end, we present a study of the history of beer brewing in the Canadian province of Ontario by paying specific attention to the recent emergence of craft beer brewing. We argue that the craft brewing renaissance in Ontario is related to the creation of a new collective identity by local brewing entrepreneurs who recovered important identity remnants from the industry's past. We analyze existing historical narratives of the evolution of beer brewing in Ontario and map the shifts in the collective identity of beer breweries over time. We categorize our time line into five periods and examine identity elements that mutated, were discarded, or became adopted in each period. We then focus on the emergence of craft beer brewing in Ontario and assess to what extent and in which manner the newly formed collective 
identity of craft breweries builds on identity elements that were previously left behind. We assert that the new collective identity of craft brewing was constructed on a revival of the ancestral meanings of beer brewing as community activity and as craft through the return of small-batch brewing technology, the resurrection of old product styles, and the reinvention of the tavern as an important part of the distribution chain.

This paper proceeds as follows. First, we provide a brief discussion of the theoretical constructs that we draw upon in the paper, focusing specifically on collective identities and institutional remnants. Next, we present a selective reading of the social history of beer brewing in Ontario from which we construct a historical narrative covering five sequential time periods. We ultimately show how the new craft brewing identity recycled and reinvented identity elements that were discarded during previous time periods. We conclude the paper by advocating for more research on the influences of the past in the emergence of new collective identities in established fields.

\section{CONCEPTUAL FRAMEWORK}

In the following sections we introduce and review the concept of collective organizational identity and discuss the some of the limitations of the current theory. Next, our discussion turns to those elements of the past that have been left behind in an organizational field. These we call "remnants of the past" and we explore how these elements can be used to develop collective identities. We conclude with an overview of our data and the process by which we examined the historical narratives of our study within the context of our conceptual framework.

\section{Collective Organizational Identity}

Organizational identity is most commonly defined as a set of claims about the central, distinctive, and enduring attributes that characterize an organization and thereby position it in a 
social category. ${ }^{16}$ As a phenomenon related to organizational culture, ${ }^{17}$ identity claims focus on what or who an organization is by identifying its institutional classification, relational association, or behavioral commitment. ${ }^{18}$ For example, a brewery could be identified through its strategic form as a "brewpub" or in association with a specific community as "the local brewer". In the organizational literature, this view is most closely aligned with a sociological perspective known as institutional identity. ${ }^{19}$ According to this view, identity is claimed in reference to cultural resources that are embedded in the external environment as socially constructed knowledge about types of organizations and their typical identity attributes, such as core values, practices, and products. ${ }^{20}$ The mutual recognition of such a claim by organizations and their stakeholder audiences is crucial for successful identification and an important outcome of successful identity claims is organizational legitimacy. ${ }^{21}$

Multiple organizations in the same environment may develop shared awareness of a collective organizational identity by virtue of their common claim to the same set of identity attributes. ${ }^{22}$ Collective identity claims may reference attributes such as core production methods $;{ }^{23}$ administrative processes $;{ }^{24}$ stakeholder relations in the value chain $;{ }^{25}$ product strategies; ${ }^{26}$ and geographic location. ${ }^{27}$ For example, craft breweries are often identified based on their production technology, target consumers, and geographic markets. ${ }^{28}$ At a more abstract level, collective identities may also link an organization to a logic that imbues it with meaning in relation to a coherent system of values and beliefs in the broader environment or institutional field. ${ }^{29}$ Correspondingly, organizations are identifiable in reference to the logic of status rankings in an industry ${ }^{30}$ or the logic that defines basic organizational purpose and value premise. ${ }^{31}$

Collective organizational identity is rooted in organizational isomorphism with prevailing institutions and establishes boundaries between organizational types. This means that a group of 
organizations with a common collective identity have attributes that are prototypical (i.e., central) of the group and attributes that distinguish it from other groupings of organizations. The resulting structural configuration of the collective identity is known as legitimate distinctiveness because it establishes recognition and acceptance. ${ }^{32}$ While these ideas illustrate how collective identity legitimates organizations through claims of central and distinctive character, the way collective identity claims imply endurance over time is not well understood. Some research on temporal aspects of collective identity is beginning to explore how groups of firms in new fields legitimate a new collective identity by claiming identity attributes that permit a flexible interpretation of the group's core values and practices or link them to the practices and values of other established organization types. ${ }^{33}$ Other research has investigated how groups of firms in an established field demarcate a collective identity from that of incumbent organizational forms by claiming identity attributes that resonate as authentic with a specific customer base. ${ }^{34}$ However, neither stream of research addresses how claims that symbolize a historical basis of collective identity may generate legitimacy. Identity claims symbolize an enduring organization in the sense that labels for identity attributes persist over time even as meanings associated with those labels may change, ${ }^{35}$ and meanings of organizational identity are frequently informed by past organizational practice and values. ${ }^{36}$ Therefore, one component that may facilitate the acquisition of legitimate distinctiveness is the ability to identify and draw on the remnants of past incarnations of organizations that have populated the organizational field throughout history.

\section{Remnants from the Past}

We thus propose that new collective identities may emerge out of institutional remnants from the past. As fields mature and collective identities shift, populations of organizations and their supporting institutional structures come and go. However, even after a field has settled on a particular institutional path, the remnants of alternative institutional orders and associated 
ancestral organizations may continue to play an important role in present-day organizational dynamics. They may cast legacies that continue to shape current institutional environments ${ }^{37}$ or their remnants may provide concrete entrepreneurial resources for the construction of novel organizational elements. ${ }^{38}$

For example, Greve and Rao argue that ancestral organizations make imprints on their environments in the form of legal structures, organizational blueprints and network ties that continue to survive even after the demise of these organizations. Similarly, Schneiberg suggests that defeated organizational configurations leave behind "flotsam and jetsam" which "constitutes resources or building blocks for institution [and organizational] assembly, rehabilitation or revival... [and which] can be redeployed to support new experiments, theorization, mobilization for change and even the consolidation of entirely new paths within existing systems". 39 In addition, even when actionable technical resources associated with ancestral institutions and organizations disappear, their identities may survive in collective memory albeit in a more latent form. Dobrev (2001) shows how post-socialist Bulgarian newspapers profited from the existence of the cultural legacy left in the remains of pre-socialist newspapers by actively reviving ancestral identity elements (such as names and logos). This suggests that institutional remnants can provide fertile resources for the construction of new collective identities. Because the remnants were rooted in enduring identity attributes they provided the newspapers with both a source of legitimacy and a point of difference. Re-incorporating discarded identity elements from the past is likely to re-activate dormant legacies, thereby enhancing socio-cognitive support from the organizational environment. Moreover, in contexts dominated by incumbent organizational populations, such recycling activities are also likely to produce distinctiveness because those incumbent organizations have typically had to distance themselves from ancestral institutions in favour of the prevailing institutional configuration to secure their survival. It is for this reason that change initiatives are often effectively framed as attempts to restore or revive ostensibly enduring traditions. ${ }^{40}$ 
Despite this previous work, the understanding of how new collective identities may be constructed from remnants of the past is relatively limited. In the following section we present an analysis of the history of beer brewing in Ontario over the past two hundred years. This is not meant to be an exhaustive exploration of the industry's evolution but a depiction of important social and cultural developments that enable us to understand how remnants accumulate over time before being resurrected. In doing so, we aim to address how institutional remnants from the past may have shaped the craft brewing collective identity that emerged in the Ontario beer brewing industry.

\section{Methodological Approach}

Our analysis entails three components. First, it provides a synthetic overview of the history of the beer brewing industry in Ontario. Second, we pay specific attention to the emergence of different collective identities. Third, we focus on identity elements that were discarded at one point in time but were later recycled back into the system. Because collective identities are intertwined with the wider institutional environment, we focus on their construction and legitimation in relation to broader social developments. ${ }^{41}$ Our historical examination to capture these three components takes two complementary and inter-related approaches. The first, a contextual analysis, is concerned with understanding institutional arrangements during a specific period in time. ${ }^{42}$ The second, a longitudinal analysis, focuses on the causal processes that link different time periods through the occurrence of events to which organizational actors responded in the context of their contemporary institutional arrangements. ${ }^{43}$ Similar to events that can serve as catalysts for institutional change, ${ }^{44}$ historical events can serve as a marker of transition, and interpreting the importance and meaning of such transition links the contextual and longitudinal parts of our analysis. ${ }^{45}$

Thus, our methods were necessarily qualitative and exploratory. We used historical records and narratives from the past along with insights and concepts from organizational theory to develop a coherent story of collective identity in the Ontario beer brewing industry from its 
origins to the early $21^{\text {st }}$ century. We identified major events and phases in the history of the industry of commercial beer brewing in Ontario so that we could paint a rich picture of the meanings and practices associated with beer brewing and how they changed over time. ${ }^{46}$ Most of our historical data are obtained from secondary sources and historical narratives available in published format, which we examined by interpreting the underlying and evolving patterns of social organization in an event-history fashion. ${ }^{47}$ We present our results as five consecutive time periods punctuated by key events. In each time period, we first introduce those events and then explain in our narrative how they relate to the contemporaneous patterns of social organization relevant to collective identity.

There are several reasons why Ontario was an appropriate site to explore our research question. Ontario was the principal area of British settlement from which Canada developed into a nation, and data were available to cover the origins of beer brewing and its cultural significance in the context of the broader institutional environment. Second, the Ontario brewing field constitutes a small but unique market that can be studied separately because Canadian legislation gives provincial governments jurisdiction over the distribution and sale of alcoholic beverages. Thus, it is possible to consider the evolution of Ontario's beer brewing industry as a system with relatively clear social boundaries.

The analytical questions we used to examine the historical data were guided by our conceptual orientation and focused on interpreting the collective identities of beer breweries indirectly by examining the role breweries played, as an organizational type, in relation to other field participants over time (e.g., organizations in the value chain). These questions are: (1) what were the key stakeholder relations developed and maintained by breweries; (2) what were the main consumptive practices of those who used the products of breweries and (3) what were the main production factors that breweries implemented to manufacture, distribute and sell their products? In order to integrate answers to those questions within out contextual-longitudinal analysis, we aimed to maintain a coherent narrative of the collective nature of beer brewing in 
Ontario and construct an overarching story that captures the "common meaning system" of all actors in the field. ${ }^{48}$ Table 1 provides a summary of our main findings, displaying information relevant to our analytic questions, systemic meanings, and other facets of the beer brewing field over time. In our narrative, we highlight specific events that disrupted the field and created institutional remnants. We summarize our findings in relation to how key events shaped the inter-organizational structure of the field in Figure 1.

Insert Figure 1 and Table 1 about here

\section{A HISTORY OF ONTARIO BEER BREWING}

The following sections are an examination of the historical narratives of the Ontario beer brewing industry. We have identified five periods (Beginnings, Temperance, Prohibition, Restoration and Revival) that the industry has passed through over nearly 200 years of existence. We present each period by focusing on stakeholder relations, consumption practices, and production factors, integrated by ideas that express underlying field-level meanings.

\section{Beginnings: The brewery as pillar of the community}

\section{Stakeholder Relations}

The primary collective identity of breweries in the early beer brewing industry appears to have been as a key member of the community, as evidenced below by a number of key practices and inter-dependencies with important stakeholders. A brewery "was one of the first construction enterprises in a new settlement", ${ }^{49}$ and beer consumption was associated with meals at communally organized work projects known as pioneer bees. ${ }^{50}$ In addition, this community collective identity prior to 1864 is evident in the role the brewer played as communal food supplier, providing sustenance to British soldiers and travellers. The identity was likely linked to a general acceptance of alcohol consumption as part of every-day life and the diffusion of beer brewing as a domestic and farming activity (See Figure 1). This description of the emerging 
industry dovetails with anthropological studies about the ritual meaning of beer drinking in North-America or Protestant Britain ${ }^{51}$ and parallels other historical accounts of beer brewing in the new world colonies. ${ }^{52}$

Evidence suggests that during the emergence of beer brewing in Ontario (known at that time as Upper Canada) the brewing trades maintained a symbiotic relationship with the British Army for the supply of foodstuff. The first commercial breweries in Ontario were established in the late $18^{\text {th }}$ century near military barracks in Kingston and York (Toronto), and by 1850 a brewery had emerged in every garrison town. ${ }^{53}$ A likely reason for the apparent interdependence between brewer and military was the nutritional value of beer, which is recognized in the brewing history of not just Canada but the world over. Malt was considered a good source of nourishment and small beer (2-3\% alcohol content) a bacteria-free water substitute. ${ }^{54}$ Spruce beer, made with the spring roots of spruce trees, was seen as a significant source of Vitamin C used to fend off scurvy. ${ }^{55}$ All British military personnel were entitled to daily beer rations until 1800, when rations were replaced with "beer money", thus precipitating early market dynamics. ${ }^{56}$ Bowering notes that so-called "wet canteens" were typically located near the entrances to army barracks, operated jointly by a local brewery and innkeeper and set up for soldiers to redeem their beer money. ${ }^{57}$ Altogether, the interlocking activities of beer brewer, army, and canteen suggest that the collective identity of breweries was symbolic of local community development.

\section{Consumption Practices}

Connected to the collective identity of the beer brewing industry at this time was the tavern. As a key part of the community, there were a number of different functions that the local taverns played. In particular, because town halls were not common in Ontario during the first half of the century, the tavern was typically the only public building and, therefore, used for all sorts of communal activities, including political meetings, court sessions, and church services, at which alcohol consumption was a normal occurrence. ${ }^{58}$ The tavern also played a role in settling 
the country because it was the principal place to house travellers and a key source of food and drink, including beer, for the men working in local industries. ${ }^{59}$ Most historical accounts suggest that whisky, rather than beer, was the beverage of choice in taverns. ${ }^{60}$ The first available census data from 1851 shows that per capita beer consumption in Ontario was only one quarter that of liquor. ${ }^{61}$ Nevertheless, a number of brewers were also innkeepers or supplied the community taverns. ${ }^{62}$ Based on the above ideas, we conclude that the strategic role of downstream organizations in the distribution chain of commercial beer brewing (i.e., taverns and wet canteens) was primarily a venue for food supply to community stakeholders (e.g., civic parties and the military) and less a site for retail sales to individual or civilian consumers. The latter is most likely to have been the domain of farmers.

\section{Production Factors}

The primary collective identity of the beer brewer as a foundation for the community is also implied by production, distribution, and regulatory factors. Traditional brewing technology imported from the old world (e.g., small batch processing, sale of unfiltered products) connected local brewers by a common heritage. ${ }^{63}$ In the absence of scientific knowledge about the fermentation process, early breweries possibly attempted to protect their commercial status in the community by defining their work as "mystery and craft". ${ }^{4}$ The ales of the time tended to be stronger in taste and potency than today's products because brewers hid off-flavours with higher alcohol content and ensured preservation by adding large amounts of hops. ${ }^{65}$ Given the rudimentary transportation and refrigeration technologies of the time, breweries were always local enterprises and beer brewing was a common domestic activity. It is also highly likely that a number of brewers were farmers who spent the otherwise idle winter months brewing from leftover grain and supplying their output directly to individual consumers. ${ }^{66}$ Given that bottling technology was not yet adequately developed and evidence suggesting that beer was not commonly sold through stores at the time, it is possible that competition among farmers and home brewers may have existed in the form of locking in customers through personal 
arrangements. ${ }^{67}$ Production was regulated through taxes levied on malt and distribution through locally issued and easily attainable innkeeper's licences. ${ }^{68}$ These factors all strengthened the interdependence among various brewers and their clients through a community logic (see Figure $1)$.

After the middle of the 19th century, the field underwent a major transformation and was characterized by attacks on the legitimacy of beer brewing as well as a major increase in the number of breweries (See Figure 2), as discussed below.

Insert Figure 2 about here

\section{Temperance: The brewery as a local business}

As an industry, brewing in Ontario came of age in the second half of the 19th century and along with this industry growth a new collective identity emerged: breweries as commercial businesses. We trace this change to significant upheaval that affected the inter-relationship between beer breweries, their clients, and wider society. Because of the protracted nature of several events underlying those changes, we chose 1850 as a key starting date for this period because it marks the middle of the century and falls roughly at the midpoint of the period during which the events unfolded. Specifically, we argue that in conjunction with pressure to secure a customer base and the availability of new production methods, the emergence of temperance fomented changes in key stakeholder relations that led the collective identity of the brewing industry to shed its more intimate communal face and adopt a more impersonal business face. At a deeper societal level, beer brewing was no longer understood as foodstuff production but more as a commercial activity.

\section{Stakeholder relations}

Following the rebellion of 1837 , the British began to withdraw their troops from Ontario, prompting a wave of relocations and failures among the breweries adjacent to the vacated 
barracks. ${ }^{69}$ The sudden disappearance of a key stakeholder who supplied significant resources to the field meant that breweries had to look for new customers to ensure survival, a task significantly complicated by temperance. As a social movement, temperance began prior to midcentury but gained significant momentum with the enactment of the Dunkin Act in $1864{ }^{70}$ which introduced local option laws to Ontario that allowed municipalities to enact prohibition if a simple majority agreed in a verbal vote. "Old pledge" temperance, during the 1830 s and 1840s, was targeted specifically at liquor and spirits, but not wine, beer, or cider, while temperance agitation, following the Dunkin Act, was aimed at all alcoholic beverages (i.e., the "new pledge" $).{ }^{72}$ New pledge forces achieved prohibition in most of Ontario by the end of the 1860 s, but many municipalities repealed due to pressure by anti-temperance groups and the difficulty of enforcing prohibition. ${ }^{73}$ In 1878 , the federal Scott Act replaced the Dunkin Act, making enactment of local prohibition easier by lowering the minimum petition required to force a vote, but only half of all such votes taken in Ontario were successful. ${ }^{74}$

\section{Consumption Practices}

In this context, competitive, societal, and technological changes interacted to foment new meanings and behaviours associated with commercializing and consuming beer. Perhaps the most obvious example is a repositioning in the meaning of the tavern from the locus of communal activity to a retail outlet for beer consumption. The rise of temperance and the disappearance of the British army prompted a reinterpretation of what it meant to be a tavern and the overall role played by the tavern in the community. When enacted, temperance affected the distribution chain in the beer brewing field, producing two key threats for taverns: (1) temperance societies were organized in part to provide alternative venues for holding the social and community events that had normally taken place in taverns and (2) industrial growth, urbanization, and attendant desires for social mobility in general fostered temperance beliefs among the middle class. ${ }^{75}$ Guillet records a drop of over $60 \%$ in the number of hotels and taverns listed for Toronto between 1850 and 1860, which he attributed, consistent with our arguments, in 
part to rising temperance sentiment and changes in tavern designation to wholesale/retail outlets. $^{76}$ Nevertheless, by the 1870 s, the number of taverns had almost quadrupled again, and there were 533 licensed places to sell alcohol in 1874 in Toronto alone. This number fell once more two years later, just prior to the Scott Act, as city council restricted the number of tavern and beer-shop licences to $315 .^{77}$ These changes likely reflect fluctuations in temperance sentiments within the province and local responses to the various forms of legislation.

More importantly for our focus, the changes suggest that taverns may have responded to the threat of temperance agitation by shifting their business from selling mostly liquor to selling more beer. The number of breweries in Ontario shows a significant growth trajectory between 1840 and 1870 (see Figure 2). With the number breweries in Ontario stabilizing, Canadian beer production rose six-fold between 1871 and $1910 .^{78}$ At the same time, the percentage contribution to overall alcohol consumption of beer rose from $15 \%$ in 1871 to $35 \%$ by 1893 , while that of spirits fell from $81 \%$ to $63 \%$, with wine remaining constant. ${ }^{79}$ In Ontario, per capita consumption of beer doubled between 1871 and the turn of the century, while that of spirits decreased by $50 \% .^{80}$ This old pledge temperance effect is also mirrored by the Crook's Act of 1876, which accorded lower license fees to retailers who only sold alcoholic beverages of less than $15 \%$ alcohol content. ${ }^{81}$ Thus, in the context of temperance, the interdependence of brewery and tavern intensified as the distribution chain in the industry converged on taverns and stores. We argue this change is consistent with the emergence of a commercial business identity that replaced the previous community identity of beer breweries.

Related to the effect of temperance on the relationship between beer brewery and tavern, we impute that beer consumption came to be culturally understood less as nourishment or food consumption, and more as a leisure activity. Specifically, we argue that the advent of lager brewing technology mitigated the threat of temperance because it enabled beer breweries to position their products as a "lesser evil" in comparison to those produced by distillers, as we discuss next. 


\section{Production Factors}

The introduction of lager brewing technologies can be regarded as a final contributing factor to the change and upheaval in the brewing industry during this time period. Although the first Ontario lager brewery made beer in 1837 , it was only after local option laws were introduced that the ale-producing breweries in other areas of the province started to brew lager. ${ }^{82}$ Our data show that the largest annual jump in the number of breweries occurred in 1864 , the year of the Dunkin Act. Thus, the field responded to temperance by spawning more producers and brewing more beer, and we propose that the adoption of lager brewing processes may be a key to this development. Compared to ale brewing, the new production technology inhibited bacteria growth, introduced more biology and chemistry into the brewing process, and resulted in a product that was less opaque in appearance, lighter in taste as well as colour, and lower in alcohol content than traditional ales. ${ }^{83}$ These qualities may have appeased temperance forces by creating a contrast to those of liquor or traditional ales, and the use of scientific principles may have legitimated lager production in the eyes of elites.

At the societal level, an increase in demand for lager beer suggests that field level beliefs about what consumers and society demanded affected the production strategies of breweries, which were likely to have seen lager brewing technologies as a means to stay alive and achieve legitimate business status. ${ }^{84}$ While some breweries switched to lager brewing, the costs of lager production discouraged many others, who instead adapted pieces of the new production techniques to make their ales lighter in colour, alcohol strength, and taste. ${ }^{85}$ A perception of beer as a temperance-appeasing alternative to liquor may have developed, by which breweries survived because their new products signalled moderation in contrast to those made by distillers. Possibly in support of such newly gained opportunities, Ontario's breweries founded their own anti-temperance force in 1878, the Ontario Brewers and Maltsters Association. ${ }^{86}$ Finally, although temperance posed a significant threat, provincial brewing and related industries were considered too important to the economy by the federal government to support national 
prohibition. Thus politicians, on the grounds of low voter participation, disregarded a national vote marginally in favour of prohibition in $1898 .^{87}$

Competitive practices also evolved and signalled the advent of a new collective identity as commercial business. Having found a new method of production, breweries responded by competing for the business of not just local customers but also customers in neighbouring dry areas, ${ }^{88}$ a phenomenon that similarly occurred at the inter-state level in the US, where it led to significant improvement in brewery survival chances. ${ }^{89}$ Improved transportation and refrigeration technologies may have further aided the geographic expansion of markets, ${ }^{90}$ and the use of bottles became more widespread as transportation of bottles across municipal boundaries was less conspicuous than that of barrels. ${ }^{91}$ Logically following geographic expansion, the average size of breweries increased during the second half of the $19^{\text {th }}$ century and the first types of advertising emerged in the form of product labels and other means to obtain business differentiation $^{92}$.

As beer brewing in Ontario came of age, some factors appear to have contributed to the changes in the collective identity of the industry from community pillar to business activity: an increased customer base developed because of the association of beer with leisure instead of food; commercial expansion and the detachment of the breweries from their local market; a reinterpretation of the role of the tavern in the community, and, finally, the introduction of new and more efficient brewing technologies. Breweries redefined their roles by reshaping where, how and for whom they served their products as well as what types of products they were able to serve. As a result, a new collective identity of the beer brewing industry emerged and was maintained for a significant period of time until faced with another significant industry change: Prohibition.

\section{Prohibition: The brewery as bootlegger}

The Ontario Temperance Act of 1916 and the War Measures Act of 1917 made beer sale and consumption in Ontario illegal between 1916 and 1927, closed all taverns, and subsequently 
launched a new era for the field in the form of official Prohibition. ${ }^{93}$

\section{Stakeholder Relations \& Customer Practices}

With the onset of Prohibition, 29 of 44 brewing operations that existed in 1916 went out of business over the ensuing decade. Those that survived did so because they changed their customer focus and brewed the still legal $2.2 \%$ beer, produced soft drinks, and/or exported to the US. ${ }^{94}$ Temperance societies also changed just prior to Prohibition and started to characterize alcohol not just as the source of social problems but also as an impediment to the war effort. ${ }^{95}$ However, production of beer deemed for medicinal or scientific purposes was still permitted. ${ }^{96}$ Consequently, physicians and pharmacists became new players in the brewing field through their role as downstream distributors licensed by the government, representing a merging between the meaning of alcohol distribution and other stakeholders. Hallowell reported that by 1923 nearly \$5 million worth of alcohol prescriptions were sold Canada-wide, while in 1923-24 alone some 810000 prescriptions were issued. $^{97}$

\section{Production Factors}

Ontario's breweries also lost a number of experienced brewmasters and craftsmen, who returned to Europe during the War and took with them their knowledge of the trade. ${ }^{98}$ This observation is notable because in European traditions, the brewmaster can be thought of as the figurehead of the brewery, who embodies and signifies the production ethos and vocational essence of beer brewing in cultural images. The role of the brewery had been severely confined.

Furthermore, existing breweries and opportunistic newcomers engaged extensively in back door bootlegging. Forgery of medical prescriptions was common, and some physicians even wrote false prescriptions. ${ }^{99}$ Thus, official de-legitimation was complemented by illegal activity, likely tarnishing the image of beer brewing in general and relegating the meaning of the beer brewery's identity to one of delinquent. The withdrawal of resources from the beer brewing industry in favour of the war effort implies that beer brewing may have been viewed as a potential threat to national interests. 
When examined closely, the Prohibition period can be regarded as a critical juncture in the history of Ontario beer brewing and provides a clear example of the discarding of identity elements. During this period of time, the beer brewing industry became associated with a collective identity of outlaws or miscreants, marking a definitive break in the relationship between breweries and their local communities. Beer brewing in the province was considered an illegitimate practice. Those who continued in their old practices became criminals and were marginalized. As a result, the role of the brewery as pillar of the community, once an important element of the collective identity, disappeared entirely. As we discuss next, Prohibition also had a profound impact on how the industry evolved during the post-Prohibition era.

\section{Restoration: The brewery as corporation and national business}

The next change in the collective identity of beer breweries came in the wake of the Repeal of Prohibition and the Great Depression. These two events set the stage for Ontario breweries' poor economic performance during the early 1930s and thus provided a rationale for the emergence of the new corporate brewery form. Spearheaded by Canadian Brewries Ltd., and later copied by other major brewing firms, the brewery in the second half of the 20th century became a multi-plant organization with a corporate agenda, national markets, diversified interests, and mass production technology. State-mandated centralization of the distribution system in the form of Brewers Warehousing and Brewers Retail also represents a significant difference to prior times, involving hierarchical rather than market-based coordinating mechanisms. ${ }^{100}$ This change mirrored the zeitgeist of taking responsibility for an industry in disarray following Prohibition. Increased market concentration and expanding government involvement were evidence of field-level elaboration common to beer brewing, and corporate domination spread down the value chain, as evidenced below by the fate of the tavern. ${ }^{101}$ Most notable is that the nascent identity of the brewery as business blossomed and matured into a collective identity associated with corporate capitalism and control, exemplified by production efficiency, consolidation, and rationalization. This identity was matched by changing consumer 
tastes and consumption patterns.

\section{Stakeholder Relations}

The trend toward corporate capitalism, in particular, spawned competitive strategies based on marketing. In conjunction with industry consolidation, plants with large brewing capacity began to take over the output of several brands for the entire province and breweries adopted high gravity brewing methods, ${ }^{102}$ as a result of which product variety and distinctiveness declined. Marketing and life-style advertising became the dominant means of differentiation among the major breweries, a development which parallels that in the US. ${ }^{103}$ As distribution regulation through Brewers Retail prevented price competition, even staunchly conservative companies like Molson Breweries of Montreal adopted modern advertising techniques following its entry into the Ontario market. ${ }^{104}$ The basis of those ads was identification with a social lifestyle, targeted primarily at the 19 to 34 old male customer segment. ${ }^{105}$ This has led to the association with sporting and cultural events, such as Hockey Night in Canada, which have become an illustrative pillar of competitive positioning in the beer brewing field.

\section{Consumption Practices}

A somewhat similar process occurred with the marginalization of the tavern during this period. Although the tavern had been reintroduced to the field by the 1934 Amendment to the Liquor Control Act, it never managed to re-establish its key position in the distribution chain of the second half of the 19th century. Statistics show that per capita consumption of beer in Canada fell from 6.2 gallons in 1928 to a low of 3.7 gallons in 1933 and then rose back to just below 6 gallons in 1939, indicating that legalized public consumption is likely to have contributed to the revival of Ontario's breweries. ${ }^{106}$ However, long-term developments indicate that the tavern played a diminished role in the industry. Between 1948 and 1985, provincial draft sales fell from $30 \%$ to only $7 \%$ of total beer sales (see Figure 3). In addition, on-premise beer sales fell from $54 \%$ of total provincial sales in 1948 to $26 \%$ in 1980 . The data suggest that in parallel with changing product and sales strategies, the location of consumer product usage 
shifted from the tavern to the home. Better bottling, storage, refrigeration, and transportation technologies are likely to have contributed to this trend and increased the role of Brewers Retail outlets in the distribution chain. In addition, the discussion of advertising as the new competitive tool above suggests that access to new media, such as radio and television, through which breweries were communicating directly with consumers, may have made the tavern less important as a middleman in the competition for beer sales.

Insert Figure 3 about here

Public consumption of beer remained prohibited and sales were kept under tight government control even after the Liquor Control Act of 1927 revoked Prohibition. Breweries were mandated to form Brewers Warehousing, first a cooperative and then a private company owned by the breweries but regulated by the province, which has controlled the sale of beer through its Brewers' Retail stores to this day. ${ }^{107}$ Some breweries hired former bootleggers as sales representatives, known as "runners," whose dubious methods to sell to individuals for home consumption continued to cast a negative image on the industry. ${ }^{108}$ And, although the number of breweries rose from 15 in 1927 to 36 by 1930, they operated well below 25\% capacity ${ }^{109}$ while per capita consumption declined steadily during the Great Depression until 1933. ${ }^{110}$

\section{Production Factors}

After the Great Depression, the field experienced a decade of growth and consolidation. Provincial production increased from a 1933 low of 344,000 barrels to 2 million barrels by the end of World War II, and capital investments surged from a 1937 low of $\$ 17$ Million to $\$ 25$ Million in 1942. ${ }^{111}$ This boom, however, was followed by increasing concentration and government regulation. Industry consolidation and modernization was pioneered by E. P. Taylor, who merged almost half of Ontario's breweries into a holding company called Canadian 
Breweries between 1929 and 1940, precipitating a steady decline in the number of independent Ontario breweries, which would characterize developments in the field until the 1970s (See Figure 2). ${ }^{112}$ In the early 1930 s, most breweries were in such poor economic conditions that E.P. Taylor's strategy to consolidate them into one company with centralized control and fewer, larger plants that could realize greater scale economies, made financial sense for buyer and sellers alike. ${ }^{113}$ Taylor modelled his company after a similar organization in Quebec, and his strategy also mimics the government's mandate to centralize the distribution system. ${ }^{114} \mathrm{He}$ spearheaded mass production by shutting down nine of fifteen acquired breweries, modernizing the remaining ones to become more efficient, and brewing fewer brands. ${ }^{115}$ We suggest that these actions are signs of a time when Fordism and scientific management became prominent features of Canadian manufacturing and industrial organization.

Evidence of Taylor's successful consolidation strategy is that production capacity per brewing plant increased from 1 million gallons among 18 independent brewing companies in 1940 to 5 million gallons per plant among 6 companies in $1965 .{ }^{116}$ In addition, two other brewing companies, Labatt of London, Ontario, and Molson, of Montreal, Quebec, copied Taylor's model. Both became publicly traded corporations in 1945 and pursued a similar consolidation strategy as Canadian Breweries, yielding what was known as the "big three" brewing companies and acquiring all but one of Ontario's independent breweries by the 1970 s. $^{117}$ At the height of consolidation in 1974, the big three together with only one other independent Canadian brewing company, Moosehead Breweries of Nova Scotia, controlled $98 \%$ of the Canadian market. ${ }^{118}$ These developments symbolize the logic of industrial capitalism that characterized the collective identity of the brewery as big national business. Nevertheless, success had its price. Federal excise duties on barley malt increased by $430 \%$ between 1930 and 1942 and taxes were applied to the finished product starting in 1954. By 1994, total taxes as a percentage of national gross sales value had risen to $53 \%$ from $15.6 \%$ in 1937 and $40.6 \%$ in 1946. ${ }^{119}$ These developments unfolded in parallel with the on-going regulation of distribution 
and match a logic of managerial control inherent in the new collective identity.

A number of key responses by participants in the beer brewing industry to the developments described above can be interpreted based on the historical information. Significant traces of Prohibition can be found in the product strategies of the different breweries. For example, product strategies of Ontario's breweries were characterized by increasing focus on the largest common denominator market share, as is typical for generalist breweries. ${ }^{120}$ When Molson entered the Ontario market in the 1930s, one of its strategic objectives was to respond to changing consumer taste by making a "lighter, less bitter, and brighter brew". ${ }^{121}$ An identical observation was made by Canadian Breweries: "Results have proven that the trend is towards milder, smoother malt beverages". ${ }^{122}$ These observations suggest a continuation of the trend first observed during the temperance years, when lager brewing technology may have been a strategy for coping with social pressures. Moreover, compared to malted barley, fermentable brewing adjuncts, such as corn or rice, were not subject to federal duties. Thus, breweries faced financial incentives to use these adjuncts, which typically results in a lighter tasting product. We see here a continuation of changes in consumer preferences for lighter beers that are the legacy of temperance, as described above, and likely were reinforced by the diffusion of soft drinks during and following the Prohibition years.

An analogous observation can be made about the increasing use of science and technology in the brewing process, another practice that is evidence of a continuation from the temperance years and may have contributed to the trend toward lighter products. With mass production, beer brewing became increasingly mechanized, and it appears that "science" completely replaced the "craft" as metaphor of the production process. This was exemplified by Canadian Breweries' founding of a school for brewers and a centralized chemical laboratory, ${ }^{123}$ as well as an emphasis on modern technology and chemistry in publications of the industry association. ${ }^{124}$ The widespread use of pasteurization also contributed to the removal of bitter flavours from beer, as did product innovations and improvements made on the basis of process 
technology rather than raw materials (e.g., dry beer, ice beer, and light beer). ${ }^{125}$

The reinterpretation of the role of beer breweries in society was also apparent when, in conjunction with consolidation, Ontario's breweries continued geographic expansion of their markets to become national companies. An important symbol of their strategy of expansion and consolidation was the obfuscation of identity elements from the local and regional past and the appropriation of identity elements associated with a broader national presence, which became particularly apparent after WWII and the rise of Canadian nationalism. ${ }^{126}$

Although some breweries had already modelled expansion into the US through illegal export during the Prohibition era, Canadian Breweries pioneered legal exports to the US as well as the first inter-provincial brewery acquisition in the 1930s. ${ }^{127}$ Soon after the Second World War, ${ }^{128}$ both Molson and Labatt joined Canadian Breweries in the inter-provincial acquisition and consolidation game and the big three have dominated the national market since. ${ }^{129}$ This strategy, rather than even larger plants, made sense in Canada because inter-provincial trade barriers prevented breweries from selling in a province where they did not also produce. Thus, Ontario breweries that were once local, family-based, businesses became part of publicly held corporations focused on efficiency and diversification into non-brewing activities. ${ }^{130}$ Ironically, the competitive practice of absorbing family-owned breweries can be seen as one of the sources of remnants used to construct a collective identity for the craft beer industry, as discussed below. Because many family-owned breweries were shuttered, this meant that sizeable amounts of physical and symbolic organizational elements had to be discarded. The result was that new breweries were able to obtain equipment and, possibly, know-how about the brewing process that they used to produce new, craft beers in the 1980s.

In summary, historical evidence suggests that there was a dramatic shift in the collective identity of beer breweries, which went hand in hand with the disavowal of various identity elements that had previously been part of the field. Beer brewing was no longer intertwined with local communities and stakeholders, and the idea of beer brewing as craft had gradually been 
discarded. The dissolution of these two organizational identity features was observable in the concrete and symbolic organizational material that was discarded. The closure of traditional breweries during this wave of concentration led to the discontinuation of many brands, the disposal of production equipment, and the abandonment of local brewing traditions. On a broader scale, this led to the disappearance of particular styles of beer (e.g., stout), associated production methods (small-batch, nonfiltration), and related distribution networks (taverns). Meanings associated with community and craftsmanship in brewing remained dormant and buried in advertising that expressed Gemeinschaft through participation in sporting events and Gesellschaft as national industry.

\section{Revival: The Return of Community and Craft Brewing}

In the 1980s, a new collective identity emerged among the different breweries in Ontario and elsewhere in North America: The craft brewery. ${ }^{131}$ Similar to developments in the US, the craft brewery in Ontario most likely emerged in part because the generalist strategies of national breweries opened up resources that new breweries accessed through differentiation strategies. ${ }^{132}$

Growing consumer demand for imported beers and legislative changes that permitted the establishment of brew-on-premises operations and brewpubs further opened up a niche for craft breweries. ${ }^{133}$ The developments are linked also to consumer social movements, such as CAMRA (Campaign for Real Ale), which originated during the 1970s in the UK to advocate for the return of traditional beers and found a following in Canada. Thus, consumers in search of product diversity and authentic brewing craft, as well as former homebrewers, were among the pioneers of Ontario's craft brewing industry, such as Brick Brewing of Waterloo and Wellington County Brewery of Guelph. ${ }^{134}$

Since the first Ontario craft brewery opened in 1984, a renaissance similar to those in the US and other Canadian provinces has been under way in the beer brewing field. Figure 2 shows that the number of independent breweries has grown steadily since 1985 and counted 52 companies by 2001: 27 micro-breweries, four regional breweries, two national breweries, two 
contract breweries, and 17 brewpubs, some of which contract brew with provincial craft breweries. ${ }^{135}$ New craft breweries captured approximately a $10 \%$ market share and accounted for the only growth in the industry at that time. Concurrently, the big breweries fought primarily over capturing marginal gains in market share of the stagnating mainstream segment. ${ }^{136}$

The first Ontario craft breweries and brewpubs aimed to meet the demand for a product that had the characteristics of imported beers and was different in quality, not marketing image, from the products made by Molson and Labatt. ${ }^{137}$ These breweries were strikingly different in form and strategy from the existing ones and many more have followed their pattern. In retrospect, we can see that the early entrepreneurs who founded the first craft breweries relied on the institutional remnants of ancestral populations of breweries to develop a new collective identity by reincorporating traditional meanings of beer brewing for use in the context of the modern brewing industry.

Stakeholder Relations

An excellent example of the re-emergence of past identity elements is the focus on geographic location as a means of constructing and enhancing a new collective identity connected to traditional brewing communities. In the first few years of this period, most Ontario craft breweries restricted distribution to local or, at most, provincial markets. Today, considerable variation can be observed, with brew-pubs clearly at the most local end of the spectrum and a few having set aim for national, and ultimately, international sales. ${ }^{138} \mathrm{~A}$ number of Ontario's craft breweries were founded in towns with a history of brewing (e.g., Brick Brewing in Waterloo), at or near sites of former breweries (e.g., Algonquin Brewing Company), or in historic buildings (e.g., Creemore Springs Brewery), signalling a geographic link with the past. Sleeman Brewing of Guelph was resurrected from the remnants of a former brewery with a different name but owned by the same family. Today's company claims that former brewery's founding date of 1834 as its own and mocks Prohibition by highlighting its continuity despite the demise of the original brewery in the 1920s. Upper Canada Brewing of Toronto signalled its 
affiliation with Ontario's historic name and Beau's Brewery of Vankleek Hill even revived the $19^{\text {th }}$ century tradition of farm brewing, co-locating beer producing and a family-run farm. Altogether, these practices are also indicative of neo-localism, which connotes a variety of social movements, including craft beer brewing, that dis-identify with the homogenization of mainstream culture by establishing connections with the uniqueness of local communities. ${ }^{139}$

\section{Customer Practices}

Another intriguing development in the Ontario brewing field before the turn of the millennium was the resurgence in draft beer consumption. Between 1985 and 1999, draft beer sales in Ontario almost doubled from $7 \%$ to $12.5 \%$ of total sales (see Figure 3). Craft breweries sell a larger percentage of their output as draft beer, which is consumed in local taverns and bars, and some breweries, including the brewpubs, exclusively sell draft beer. ${ }^{140}$ Figure 3 shows that draft sales had always represented at least $50 \%$ of total on-premise sales until about 1970 , when sales started to plummet and reached a 1985 low of $25 \%$ of on-premise sales. By 1997, this figure had reached 50\% again. Thus, it appears that with the growth of craft breweries and the increase in draft consumption, the tavern is again becoming a more important actor in the field, affecting product, distribution and other strategies of the new as well as the established breweries. By supplying directly to pubs and taverns, some craft breweries were able to side-step distribution through Brewers Retail, which is now owned by Molson, Labatt, and Sleeman and has been consistently accused of putting other, smaller breweries at a disadvantage. ${ }^{141}$

\section{Production Factors}

Finally, a significant collective identity element was located in the products brewed and the brewing process used by craft breweries in that they made beer styles not seen in Ontario since temperance (e.g., dark ales), eschewed non-malt adjuncts, foam stabilizers, and preservatives in the brewing process, and disavowed pasteurization of the final product. Craft breweries publicly touted these practices to distinguish the production ethos of their collective identity from that of the large breweries, making reference to the famous Bavarian 
Reinheitsgebot (purity edict) to legitimate themselves in the eyes of discerning consumers. While many craft breweries also contravened the Reinheitsgebot by using such flavouring adjuncts as honey, fruit, or spices, key was the symbolism of the message, which dis-identified with the mass production practices of the big breweries. The Reinheitsgebot also identified these breweries as part of the US craft-brewing renaissance, where it symbolized the revival of ancestral brewing methods. ${ }^{142}$ Consequently and probably to enhance their social status, products sold by craft breweries have been more expensive and are listed as premium category in Brewers Retail stores and taverns, compared to the domestic category that included Molson and Labatt products. Some craft breweries emphasize the connection between craft brewing and food consumption, providing recipes for using beer in cooking on their websites and teaming up with gastronomers to create new beer styles using speciality ingredients or pairing particular foods, such as cheese, with beer.

Other aspects of collective identity developed from the remnants of the past are the craft breweries' emphasis on hands-on, batch technology and the scale of the brewing operations. Craft breweries tend to be small companies that are privately owned, and have a small local base of customers. Variation can also be observed on this dimension today, as several former microbreweries turned themselves into regional firms with larger production capacity by acquiring smaller competitors, which might suggest the emergence of new hybrid brewery identity. ${ }^{143}$ As well, craft breweries proselytize the value of small batch production processes and make brews that come with an expiry date because they are not pasteurized. These methods contrasted with the large-batch or continuous production technologies and pasteurization processes still practiced by the national companies until the mid-1990s. ${ }^{144}$

Of note is that the large consolidated breweries, Molson and Labatt, have observed this trend and responded competitively to the appearance of the small craft breweries. For example, both have engaged in a de-coupling strategy to market some of their brands as craft beer and obfuscate the identity of the producer by replacing their name on the label with that of a former 
of fictitious small brewery, leading to a public relations battle between them over honesty in advertising. ${ }^{145}$ Molson opened a small brewpub named after its faux craft brand Rickard's and located it in the Air Canada Centre in Toronto, the arena for local professional sports franchises. ${ }^{146}$ This operation blended the local supply orientation and small batch production methods characteristic of craft breweries with target marketing on the sports segment typical of national breweries. Both examples suggest that the corporate breweries were experimenting with the same remnants from the past as the new craft breweries in an attempt to revive dormant identity elements of the breweries they acquired during the period of consolidation. Nevertheless, a cynical response by craft beer consumers and the perfusion of those elements through the commercial identity signal a lack of authenticity.

\section{DISCUSSION}

In this paper, we have presented a historical narrative of the evolution of the Ontario beer brewing industry, highlighting the role of institutional remnants in the emergence of a new collective identity. Our case illustrates how a new population of organizations have built upon discarded identity elements from the past to construct a legitimately distinctive collective identity in an established organizational field. Throughout the analysis, we have highlighted how events that occurred over time were linked to the structure of organization-stakeholder interactions and the collective meanings they enacted. We note that the institutional remnants of collective identity in this study evidence continuity in the way events linked an evolution of meanings about the beer brewing business over time, while the content of meanings in any one time period made sense only in relation to contemporaneous social organization. In the longitudinal element of our historical examination, the event thus highlights a point in time that was a catalyst for the abandonment or recycling of identity attributes, while in the contextual part of our analysis, examination of social structure helps understand how abandonment or recycling may have unfolded.

Brewing and breweries were initially seen as an integral part of the community life. The 
consumption of beer provided the nourishment people needed and was closely attached to the central role of the tavern as a public site for communitarian consumption and enjoyment.

Changes in consumers, technology, and social mores were responsible for the push toward the early industrialization and the emergence of the brewery as a business in the province. The development of this identity was temporarily impeded by the prohibition era. After prohibition, breweries restored their collective identity as legitimate businesses and transformed that identity into one of big business following the Great Depression and WWII. Brewing beer became a large-scale industrial operation in an industry dominated by a few corporations of national and, ultimately, global reach.

The industrialization and nationalization of breweries generated a very uniform and homogeneous market for beer that would start to see some differentiation only by the mid-1980s. The global emergence of a craft beer brewing movement and the growing interest in different types of foreign beer met with the interests of a few Ontario entrepreneurs who saw the market potential for reproducing old style beers, reviving ancient formulas and brewing methods, and resurrecting bygone brewery names, sites, and associated traditions. In a short period of time a new collective identity emerged out of this differentiation movement, and that new identity of the craft-brewery now co-exists with that of the established corporate/global brewery.

As the historical narrative suggests, identity elements that were abandoned at one stage were resurrected at a later stage, generating a new collective identity for the new craft breweries that shares similar identity features with breweries from times past. This supports the findings of Patvardhan and colleagues who demonstrated that "legacy identities" have significant influence on the development and construction of new collective identities. ${ }^{147}$ For example, some of the maverick craft breweries deliberately wanted to fill a niche by brewing a product different in quality and brewing style than the national brands. To do so these breweries resurrected products based on purportedly time-honoured recipes and coined new brand names that alluded to Ontario's brewing history. ${ }^{148}$ Similarly, new craft breweries looked for legitimacy by adopting 
the location of many craft breweries in historical brewing towns, ${ }^{149}$ and appropriating names with historical meaning, such as Upper Canada Brewing Company. ${ }^{150}$

Moreover, the collective identity of Ontario craft breweries appears to be matched by the behaviour of other actors in the field with whom they interact. Taverns and bars have assumed a more important role in the distribution of craft products than they have in the distribution of national brands, and end consumers have responded accordingly by consuming craft products on draft in those taverns. These complementary actions illustrate the social movement character of the craft breweries and their customers. ${ }^{151}$

There also appears to be congruence at a deeper institutional level of inter-locked social roles between categories of actors. ${ }^{152}$ According to this interpretation, actor types (e.g., craft breweries, taverns, beer stores, end consumers) are linked to each other by forms of interaction, including distribution and consumption practices, which are embedded in the industry's culture and had been marginalized but never vanished from collective practice. These forms of interaction are manifestations of normative beliefs, such as for example, beliefs by breweries and taverns about how to compete with other organizations, what consumers want, and what society expects. ${ }^{153}$ Similar beliefs described above about technology, competitive orientation, and strategic growth could be interpreted as evidence of macrocultural influences on organizations. ${ }^{154}$ Cognitive maps of the field may represent categorical distinctions between different types of actors and their appropriate behaviour and attributes. ${ }^{155}$ The implications of this interpretation are that relational interactions are the hallmark of collective identity and characterize the quest for "sharedness" and the social construction of new collective identities.

Another implication of our work is that it helps identify what could be considered a locus for a group's collective identity. Pratt argues that if "we can figure out where collective identity resides, we may be able to backtrack and discover how collective identities come to be". ${ }^{156}$ Our case has shown that many of the practices that characterize new collective identities are located in the institutional remnants of ancestral populations. This extends observations made in 
previous studies. ${ }^{157}$ However, whereas previous studies on ancestral population effects have typically focused on the role of institutional remnants that continue to be maintained (such as legal structures and network ties), our study suggests that attention should also be paid to the latent legacies left behind in the form of discarded identity elements that continue to be valuable even after concrete institutional support structures have vanished. In the case of Ontario beer brewing, the role of breweries as community actors and craftsmen had completely disappeared and, given the substantial gap in time between demise and re-emergence of these roles, none of the concrete institutional supporting structures were in-play. Yet, revival occurred nonetheless. The remnants of ancestral collective identities had been re-infused with value within a new institutional configuration, providing a source of identity for the re-emergence of craft-beer brewing in Ontario. This tells us that the resurrection and reinterpretation of identity elements of historical organizations may be a mechanism that produces institutional legacy effects by symbolizing endurance over time. Since our study was largely exploratory in nature, however, more research is needed. In particular, because we used secondary sources we have limited understanding of the exact activities that individual breweries engaged in to access and recycle institutional remnants and, similarly, we lack an empirical explanation of why the resurrection of legacy identities resonates with organizational audiences.

The research on bricolage also suggests some initial paths for the analysis of the reemergence of institutional identity cues. ${ }^{158}$ For instance, Glynn suggests that organizations build their identities through processes of institutional bricolage, which refers to the appropriation of existing practices, meanings, symbols, and values from the institutional environment and their recombination in new identity configurations. ${ }^{159}$ In addition to the incorporation of cultural material from present day institutions, organizations can also engage in forms of temporal bricolage ${ }^{160}$ by claiming bygone cultural meanings or practices and reinterpreting them in the face of present competitive market dynamics.

Our research also shows how a new collective identity might emerge in a mature industry 
through the bricolage of past and contemporaneous remnants from the field. Our results demonstrate how new ventures were able to legitimize a distinctive collective identity through an appeal to former organizational forms and practices and by integrating and contrasting this new collective identity with existing identities and institutions. The use of consistent and legitimate sources of meaning for identity claims (e.g., local and regional Canadian brewing history, alignment with similar cultural movements in other countries) has been an important factor in the success of craft breweries in Ontario. In fact, we believe that their strategy to position the craft brewery as an alternative, and not a substitute, to the dominant beer-brewing model has been a critically important factor in their success. Illustrative of this strategy is that craft breweries blend traditional batch brewing technology with scientific process control and the use of modern equipment. Here we see how historical bricolage may involve images about the enduring authenticity of hands-on work that are woven into the inevitable context of the modern world.

A related avenue for research concerns the role of different stakeholders in collective identity creation. Organizational audiences are of particular importance, and although they feature prominently in theorizing, they remain significantly understudied empirically. The beer brewing industry provides a fruitful setting for an improved understanding of the evolution of audience tastes in relation to changes in producer collective identities. For example, our analysis has consistently highlighted the role of beer consumption patterns, from the British Army's thirst for spruce beer, to the social preference for lager beer generated by temperance agitation, to the difference in home and on-premise consumption in the $20^{\text {th }}$ century. Analysis of product usage is rare in organizational analysis. But, to the extent that the emergence of new collective identities involves the reinterpretation and translation of patterned action we can see the strategic value of re-connecting the practices of specific consumers with specific types of organizations and the products they make. ${ }^{161}$ For example, what are breweries' and taverns' beliefs about consumers, their consumption practices, product preferences, and motivation? Do breweries and taverns engage with consumers in the collective construction of an identity for the craft beer drinker as a 
matching persona who values traditional production methods, communal involvement, and products ostensibly made according to the Reinheitsgebot? The popularity of craft brewery tours and the widespread sale of craft brewery accessories suggest that the answer is yes.

A number of organizational scholars have similarly suggested that consumer knowledge about products is an important consideration in institutional analysis. ${ }^{162}$ Thus, organizational product strategies become a key for understanding the construction of legitimate organizational identities. ${ }^{163}$ Legitimacy is commonly studied in organizational analysis by focusing on the extent to which organizational forms or practices conform to the prevailing normative social order and are comprehensible within a socially constructed reality. ${ }^{164}$ Given the findings of our analysis, an appropriate question that can be asked is: To what extent is it legitimate for a particular organizational form to produce a particular type of product? For example, are national breweries a legitimate producer of craft beer? What are the identity boundaries of each organizational form, and how might organizations be able to expand them? Is it possible that field-level collective identities, as characterized above in terms of role relations, provides for an understanding of how to appropriately combine different organizational forms and practices with particular products that are used in specific ways? To the extent that an organization deviates from such appropriate combinations (i.e., prototypes), it may not be seen as legitimate and face difficulties procuring resources. ${ }^{165}$ Deviation may lead to failure, as in the case of Upper Canada Breweries (see below), or require a decoupling strategy, as in the case of national breweries who do not disclose their identity as producers for beer brands marketed as craft type.

An interesting interpretive issue focuses on the degree of agency and constraint experienced by these new craft breweries in developing the new collective identity side by side with the existing corporate collective identity (see Table 1). The logic that characterizes the craft brewery appears to borrow cultural concepts that previously existed. For example, the craft brewery's emphasis on draft beer sales in local taverns employs elements from the $19^{\text {th }}$ century, when beer was considered a food consumed in the context of community life in the local tavern. 
"Consumers like things with history" claimed John Sleeman, CEO of Sleeman Brewing Co, whose website, like that of many other breweries, also featured extensive coverage of the history of beer brewing. ${ }^{166}$ The above evidence suggests that nostalgia, tradition, and authenticity exemplified by production methods from before the age of industrial capitalism, geographic links to the past, and brewing capacity for local markets, appear to be key features that characterized the collective identity of Ontario craft breweries at the turn of the millennium. Yet to what extent were breweries able to mix or hybridize identity elements prototypical of past and contemporary organizational identities?

For example, one of the pioneers of the 1980s craft brewing renaissance, Upper Canada Brewing, met its end after becoming a publicly held company, engaging in a brand proliferation strategy, and investing heavily in exports, marketing, and growth, attributes that are characteristic more of the corporate brewery than the craft brewery identity. ${ }^{167}$ Although Upper Canada still exists as a brand after being acquired by Sleeman Breweries, it no longer is an independent company, marking it as an organizational failure. ${ }^{168}$ More importantly, Sleeman itself has engaged on an expansion strategy reminiscent of an identity as national business by acquiring smaller breweries first in Ontario and then in other Canadian provinces, ultimately culminating in its successful acquisition by Japanese brewing giant Sapporo in 2006. Hence, Sleeman may be considered a member of what we might call a global breweries collective identity, which includes also Molson-Coors and Labatt, the latter being a part of the AnheuserBusch InBev brewing behemoth. Yet Sleeman has also adeptly compartmentalized its identity for success by keeping a low profile about its inter-provincial acquisitions and engaging in aggressive image management through heritage-focused advertisements that have upheld customer perception about its identity as a craft brewery. When Sleeman bought Brasserie Unibroue of Chambly, Quebec in 2004, the official name of the company changed to SleemanUnibroue. However, public communication on the Unibroue website maintains the former, unhyphenated name to this day and its products, unlike those under the Sleeman brand, do not 
explicitly references the brewery's name at all. Similarly, Sleeman's recent advertising campaign has highlighted the brewery's involvement in bootlegging during the Prohibition days, cheekily appealing to a rebellious and hip image that distinguishes the craft brewing collective identity from the more conservative image of the global breweries.

Research also shows that the public image of Sleeman on its website after expansion but prior to acquisition by Sapporo was markedly different than the website images of other craft breweries and projected a corporate identity more in line with those of Labatt and Molson. ${ }^{169}$ These findings imply that the success of Sleeman's hybrid identity from the perspective Ontario's craft brewing community may lie in it serving as a broker between the collective identity of craft breweries and that of the global players.

Altogether, these illustrations raise additional questions about an organization's agency to acquire historical resources, develop rhetorical histories, and manage corporate heritage. ${ }^{170}$ If the past can be a source of competitive advantage and past heritage can be successfully used to create new ventures and new collective identities, what makes some organizations better than others in recycling the past for present usage? Furthermore how do organizations acquire and make sense of institutional leftovers, and does acquisition-based growth provide equally useful past remnants compared to organic organizational growth? We can also question how organizations manage historical meanings and artifacts appropriated from the field's collective memory and whether this leads to the reinterpretation and recrafting of collective identities in a field. Although our research provides an initial attempt to answer some of these questions, future research is still needed to clarify the role of historical meanings and other institutional remnants in the development of new collective identities.

\section{Conclusion}

Our summarizing proposition is that, in parallel with a resource partitioning perspective, there has been a bifurcation of the industry into two collective identities: one that characterizes oligopolistic, generalist, national breweries and a second that characterizes the specialist, niche 
market-oriented craft breweries. ${ }^{171}$ The national breweries remain the dominant players in the industry, controlling almost $90 \%$ of the market in 2000 but experiencing a trajectory of decline. Yet, as discussed by Wade and colleagues, the craft brewery renaissance in the US is a social movement that was successful at creating a collective identity by emphasizing how craft breweries are distinct from national breweries (e.g., by obeying the Reinheitsgebot and not pasteurizing their products). ${ }^{172}$ This identity reinterprets and translates the organizational attributes and competitive practices described above into a prototypical form ${ }^{173}$ and the success of the craft beer movement is, to a great extent, constructed from remnants that are meaningful in reference to the history of the field. ${ }^{174}$ The competitive advantage created by adherence to this identity may be a cognitive strategic resource that "signifies a firm's credibility and legitimacy". ${ }^{175}$ Compliance with the attributes and behaviours of the craft brewery identity signals proper conduct and can be a source of resources from end consumers and middlemen, such as bar owners and bartenders.

To conclude, we have demonstrated that the collective identity of the Ontario beer brewing industry has undergone significant changes over the past 200 years. Of note, however, is that the recently emerging craft brewery identity is not an entirely new creation developed out of thin air. Instead, this identity borrows significantly from the institutional remnants laid down by previous generations of breweries. We suggest that the remnants of the past, if skilfully managed, can be of significant importance to how organizational members and stakeholders collectively understand who they are and the cultural meanings they share. 


\begin{tabular}{|c|c|c|c|c|c|}
\hline \multicolumn{6}{|c|}{$\begin{array}{c}\text { Table } 1 \\
\text { Primary Collective Identity Attributes in Five Time Periods of the Ontario Beer Brewing Industry } 1800 \text { to } 2001 \\
\text { (Note: Recycled institutional remnants italicized) }\end{array}$} \\
\hline $\begin{array}{l}\text { Brewery Form } \\
\text { Characteristics }\end{array}$ & $\begin{array}{l}\text { Small Breweries } \\
\text { Brewer/tavern } \\
\text { owner/operator } \\
\text { Domestic Brewing }\end{array}$ & $\begin{array}{l}\text { Mid-size Breweries } \\
\text { Family Business } \\
\text { Domestic Brewing }\end{array}$ & $\begin{array}{c}\text { Mid-size } \\
\text { Breweries } \\
\text { Family Business }\end{array}$ & $\begin{array}{l}\text { Holding company } \\
\text { Large consolidated corporation } \\
\text { Public Ownership } \\
\text { Professional administration } \\
\end{array}$ & $\begin{array}{l}\text { Small Breweries } \\
\quad \text { Brewpubs } \\
\text { Private ownership }\end{array}$ \\
\hline $\begin{array}{l}\text { Distribution } \\
\text { Practices }\end{array}$ & $\begin{array}{l}\text { Sales in local wet } \\
\text { canteens \& taverns } \\
\text { Direct supply to } \\
\text { individual consumers }\end{array}$ & $\begin{array}{l}\text { Sale in local taverns } \\
\text { and stores } \\
\text { Export to dry areas }\end{array}$ & $\begin{array}{c}\text { Medical } \\
\text { Prescription } \\
\text { Bootlegging }\end{array}$ & $\begin{array}{c}\text { Centralized distribution } \\
\text { Diversification } \\
\text { Export to US } \\
\text { Life-style ads } \\
\text { Globalization } \\
\end{array}$ & $\begin{array}{l}\text { Local sales in taverns } \\
\text { Word-of-mouth } \\
\text { advertising }\end{array}$ \\
\hline $\begin{array}{l}\text { Production, } \\
\text { Product \& } \\
\text { Consumption } \\
\text { Features }\end{array}$ & $\begin{array}{c}\text { Small batch } \\
\text { technology } \\
\text { Craft knowledge } \\
\text { Product preservation } \\
\text { Nourishment }\end{array}$ & $\begin{array}{c}\text { Scientific knowledge } \\
\text { Lager beer } \\
\text { Bottling Technology } \\
\text { Light Appearance }\end{array}$ & $\begin{array}{c}\text { Near-beer \& soft } \\
\text { drinks }\end{array}$ & $\begin{array}{c}\text { Scientific knowledge } \\
\text { Lighter beers } \\
\text { Scale economies } \\
\text { Process innovations } \\
\text { New packaging technology } \\
\text { Pasteurization }\end{array}$ & $\begin{array}{l}\text { Small batch technology } \\
\text { Craft knowledge } \\
\text { "Pure" ingredients } \\
\text { Novelty beer styles } \\
\text { Draft consumption }\end{array}$ \\
\hline $\begin{array}{l}\text { Regulatory } \\
\text { Context }\end{array}$ & $\begin{array}{c}\text { Tavern license } \\
\text { British tax on barley } \\
\text { malt }\end{array}$ & $\begin{array}{c}\text { Local option laws } \\
\text { Duties on barley malt }\end{array}$ & Prohibition & $\begin{array}{c}\text { Distribution control } \\
\text { Increasing taxation } \\
\text { Tavern licenses } \\
\text { Fewer sales restrictions } \\
\text { Advertising standards } \\
\end{array}$ & $\begin{array}{l}\text { New types of brewing } \\
\text { organizations allowed } \\
\text { More international } \\
\text { competition }\end{array}$ \\
\hline $\begin{array}{l}\text { Meanings of } \\
\text { Collective } \\
\text { Identity }\end{array}$ & $\begin{array}{l}\text { Pillar of Community } \\
\text { Army supplier } \\
\text { Food \& health } \\
\text { British Tradition }\end{array}$ & $\begin{array}{c}\text { Brewery as Business } \\
\text { Competitive market } \\
\text { Moderation }\end{array}$ & $\begin{array}{l}\text { Miscreant/Outlaw } \\
\text { Threat to the } \\
\text { nation }\end{array}$ & $\begin{array}{c}\text { Corporate Capitalism \& Control } \\
\text { Big Business } \\
\text { Industry responsibility } \\
\text { Commodification of beer }\end{array}$ & $\begin{array}{c}\text { Community business } \\
\text { Nostalgia/tradition } \\
\text { Food } \\
\text { Authenticity } \\
\text { Neo-localism } \\
\end{array}$ \\
\hline
\end{tabular}




\section{Time-line of Events and Changes in the Distribution Chain of Ontario Beer Brewing}

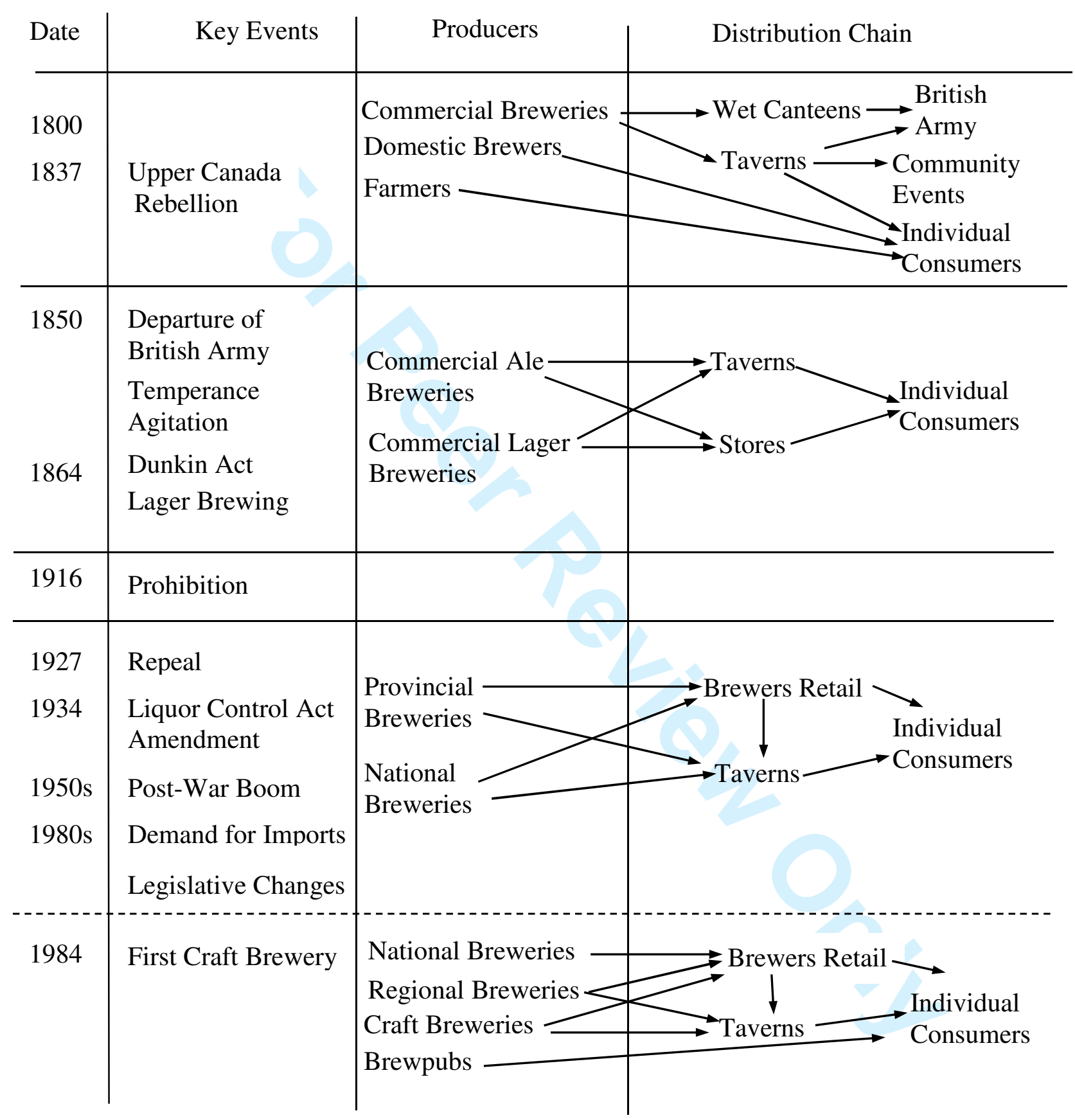


Figure 2

Count of Ontario Breweries, 1801 - 2001

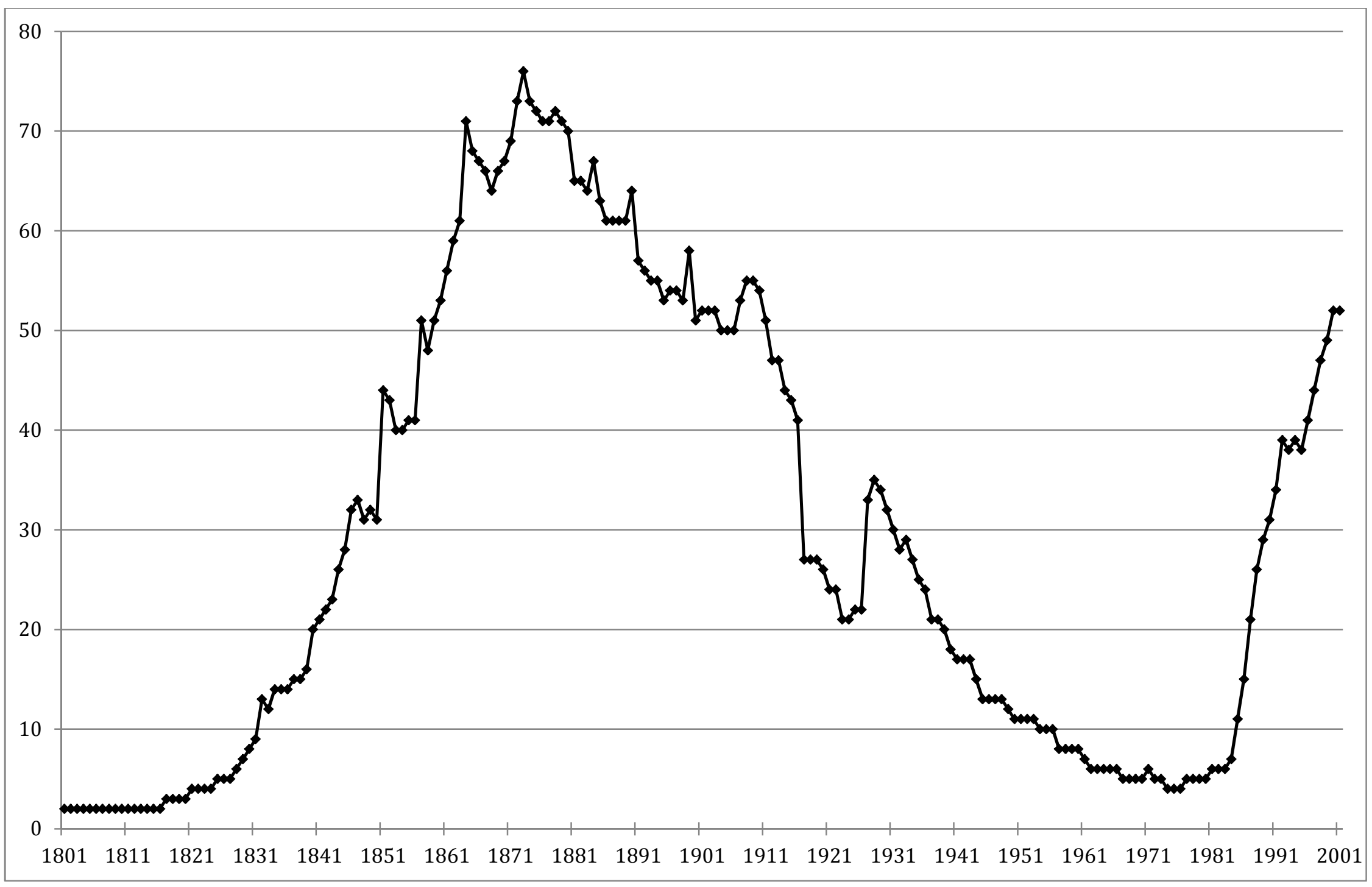

Sources: Bowering (1988; 1993); Beaumont (1994; 2001) 
Figure 3

Ontario On-Premise and Draft Beer Sales 1948 to 1997

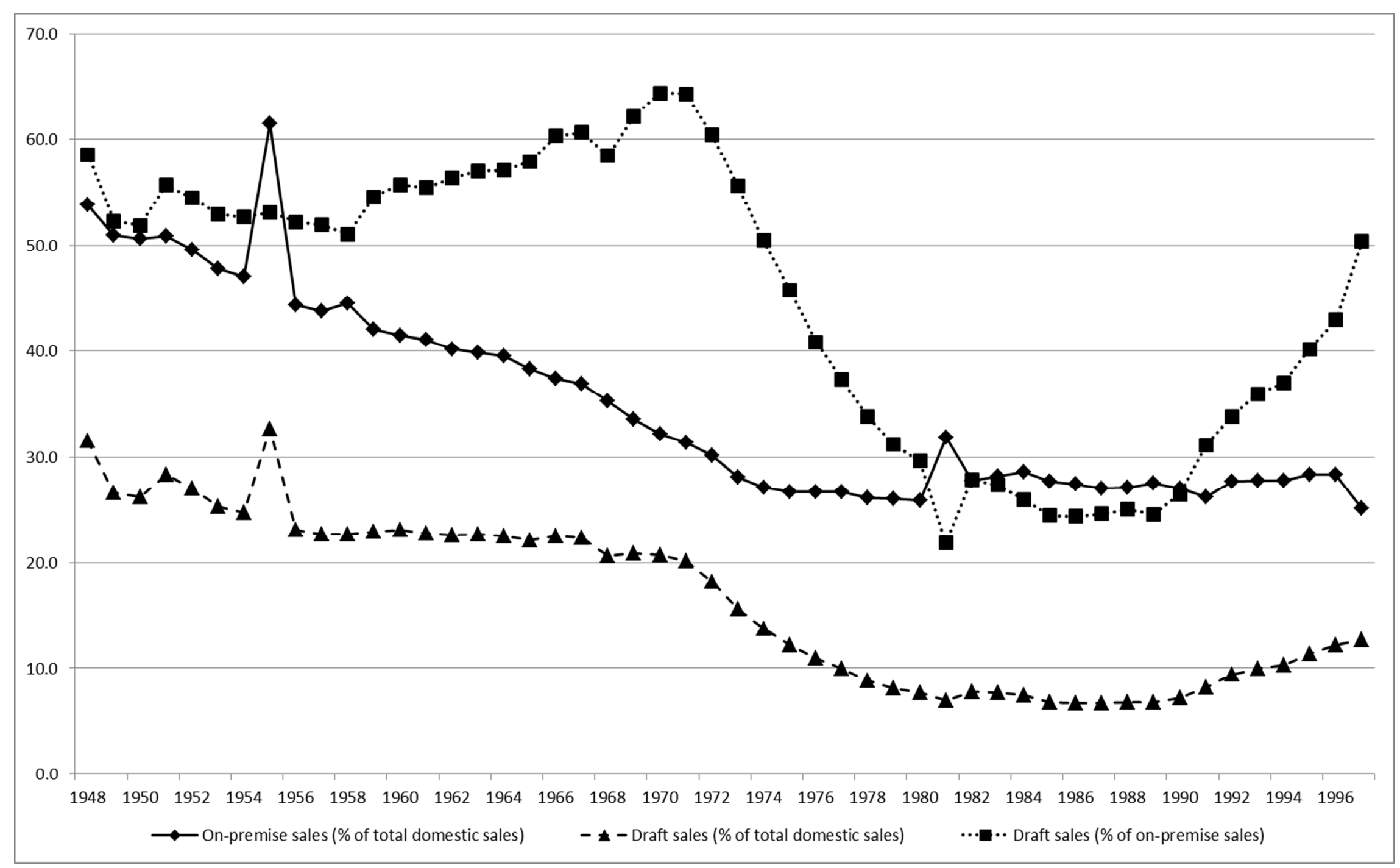

Sources: Brewers Association of Canada 


\section{References}

Abrahamson, E. and C.J. Fombrun, 'Macrocultures: Determinants and consequences'. Academy of Management Review 19, no. 4 (1994): 728-55.

Abrams, P., 'History, sociology, historical sociology'. Past and Present (1980): 3-16. Albert, S. and D.A. Whetten, 'Organizational identity', Chap., In Research in organizational behavior, edited by Cummings, L.L. and B.M. Staw, 263-951985.

Aldrich, H.E. and C.M. Fiol, 'Fools rush in? The institutional context of industry creation'. Academy of Management Review 19, no. 4 (1994): 645-70.

'Barnett's Experience Molson's Biggest Advantage', Chap., In Food in Canada, 10-141996.

Baron, J.N., 'Employing identities in organizational ecology'. Industrial and Corporate Change 13, no. 1 (2004): 3-32.

Baron, S. Brewed in America: A history of beer and ale in the United States: Arno Press, 1972.

Baum, J.A.C. and W.W. Powell, 'Cultivating an institutional ecology of organizations: Comment on Hannan, Carroll, Dundon, and Torres'. American Sociological Review 60 (1995): 529-38.

Beaumont, S. Stephen Beaumont's Great Canadian Beer Guide. Toronto: Macmillan Canada, 1994.

Beaumont, S. The Great Canadian Beer Guide, Second Edition. 2 ed. Toronto: Macmillan Canada, 2001.

'Beer Wars', Chap., In Maclean's (Toronto Edition), 26-271994.

Berger, P.L. and T. Luckmann. The social construction of reality: A treatise in the sociology of knowledge. 1st ed. Garden City: Doubleday, 1966.

Beverland, Michael B. "Crafting Brand Authenticity: The Case of Luxury Wines." Journal of Management Studies 42, no. 5 (2005): 1003-1029.

Beaumont, S. "Raising a Glass to Brewpub Culture." The Globe \& Mail1999, D5.

Boisseau, P. 1997. "The suds stud." Canadian Business, July.

Bowering, I. The Art and Mystery of Brewing in Ontario. Burnstown: General Store Publishing House, 1988.

Bowering, I. In Search of the Perfect Brew in Ontario and Quebec ... The Saga Continues. Burnstown: General Store Publishing House, 1993.

Brewers Association of Canada. Annual Statistical Bulletin: Brewers Association of Canada, 1994. Brewers Association of Canada. Annual Statistical Bulletin: Brewers Association of Canada, 1999. Brewers Association of Canada. Brewing in Canada. Ottawa: Brewers Association of Canada, 1965. Brickson, S.L., 'Organizational identity orientation: Forging a link between organizational identity and organizations' relations with stakeholders'. Administrative Science Quarterly 50, no. 4 (2005): 576-609. Brown, A.D. and M. Humphreys, 'Organizational identity and place: A discursive exploration of hegemony and resistance'. Journal of Management Studies 43, no. 2 (2006): 231-57.

Butcher, A.D. Ale \& Beer: A Curious History. Toronto: McClelland \& Stewart, 1989. Canada, C.B.o. The Canadian Brewing Industry: Historical evolution and competitive structure. Ottawa: Industry, Science and Technology Canada, 1989.

Carroll, G.R. and A. Swaminathan, 'Why the Microbrewery Movement? Organizational Dynamics of Resource Partitioning in the US Brewing Industry'. American Journal of Sociology 106, no. 3 (2000): 715-62.

Carstairs, C., '"Roots" Nationalism: Branding English Canada Cool in the 1980s and 1990s'. Social History/Histoire Sociale 39, no. 77 (2006): 235-55.

Cavanagh, J. and F.F. Clairmonte. Alcoholic beverages: Dimensions of corporate power. London: Croom Helm, 1985.

Chatman, J.A. and K.A. Jehn, 'Assessing the relationship between industry characteristics and 
organizational culture: how different can you be?'. Academy of Management Journal 37, no. 3 (1994): 522-53.

Christiansen, Lærke Højgaard and Michael Lounsbury. "Strange Brew: Bridging Logics Via Institutional Bricolage and the Reconstitution of Organizational Identity." In Institutional Logics in Action, Part B, edited by Michael Lounsbury and Eva Boxenbaum, 199-232. Bingley: Emerald Group, 2013.

Coraiola, D.M., W.M. Foster, and R. Suddaby, 'Varieties of History in Organization Studies', Chap., In The Routledge companion to management and organizational history, edited by Mills, A.J. and P.G. McLaren. New York: Routledge, 2014.

Czarniawska, B. and R. Wolff, 'Constructing New Identities in Established Organization Fields: Young Universities in Old Europe'. International Studies of Management and Organisation 28, no. 3 (1998): 32-56.

Denison, M. The Barley and the Stream. Toronto: McClelland and Stewart, 1955.

DiMaggio, P., 'Structural analysis of organizational fields: A blockmodel approach', Chap., In

Research in Organizational Behaviour, edited by Staw, B.M. and L.L. Cummings, 335-70. Greenwich: JAI Press, 1986.

DiMaggio, P.J. and W.W. Powell, 'Introduction', Chap., In The new institutionalism in organizational analysis, edited by Powell, W.W. and P.J. DiMaggio, 1-38. Chicago: University of Chicago Press, 1991.

DiMaggio, P.J. and W.W. Powell, 'The iron cage revisited: Institutional isomorphism and collective rationality in organizational fields'. American Sociological Review 48, no. 2 (1983): 147-60.

Dobrev, S.D., 'Revisiting Organizational Legitimation: Cognitive Diffusion and Sociopolitical Factors in the Evolution of Bulgarian Newspaper Enterprises, 1846-1992'. Organization Studies 22, no. 3 (2001): 419-44, doi:10.1177/0170840601223002.

Dominion Brewers Association. Facts on the brewing industry in Canada. Ottawa: Dominion Brewers Association, 1948.

Dowell, G. and R.J. David, 'Effects of ancestral populations on entrepreneurial founding and failure: private liquor stores in Alberta, 1994-2003'. Industrial and Corporate Change 20, no. 3 (2011): 82553.

Duymedjian, Raffi and Charles-Clemens Rüling. "Towards a Foundation of Bricolage in Organization and Management Theory." Organization Studies 31, no. 2 (2010): 133-151.

Eberts, Derrek. "Neolocalism and the Branding and Marketing of Place by Canadian Microbreweries." In The Geography of Beer, edited by Mark Patterson and Nancy Hoalst-Pullen, 189-199. Netherlands: Springer, 2014.

Elsbach, K.D. and R.M. Kramer, 'Members' responses to organizational identity threats: Encountering and countering the Business Week rankings'. Administrative Science Quarterly (1996): 442-76. Fiol, C.M. and A.S. Huff, 'Maps for managers: where are we? Where do we go from here?'. Journal of Management Studies 29, no. 3 (1992): 267-85.

Foster, W.M., R. Suddaby, A. Minkus, and E. Wiebe, 'History as social memory assets: The example of Tim Hortons'. Management \& Organizational History 6, no. 1 (2011): 101-20, doi:10.1177/1744935910387027.

Friedland, R. and R.R. Alford, 'Bringing Society Back In: Symbols, Practices and Institutional Contradictions', Chap., In The new institutionalism in organizational analysis, edited by Powell, W.W. and P. DiMaggio, 232-63. Chicago: University of Chicago Press, 1991.

Garud, Raghu and Peter Karnøe. "Bricolage Versus Breakthrough: Distributed and Embedded Agency in Technology Entrepreneurship." Research Policy 32, no. 2 (2003): 277-300. 
Glynn, M.A., 'Beyond constraint: How institutions enable identities', Chap., In The Sage handbook of organizational institutionalism, edited by Greenwood, R., C. Oliver, K. Sahlin and R. Suddaby, 41330. Thousand Oaks: Sage, 2008.

Glynn, M.A., 'When cymbals become symbols: Conflict over organizational identity within a symphony orchestra'. Organization Science 11, no. 3 (2000): 285-98.

Glynn, M.A. and R. Abzug, 'Institutionalizing Identity: Symbolic Isomorphism and Organizational Names'. Academy of Management Journal 45, no. 1 (2002): 267-80, doi:10.2307/3069296.

Gordon, G.G., 'Industry determinants of organizational culture'. Academy of Management Review 16, no. 2 (1991): 396-415.

Glynn, M. and C. Navis, 'Categories, identities, and cultural classification: Moving beyond a model of categorical constraint.' Journal of Management Studies, 50 no. 6 (2013): 1124-1137.

Green, D. (1998). "Micro misery." Canadian Business, November.

Greve, H. R., and H. Rao. "Echoes of the Past: Organizational Foundings as Sources of an Institutional Legacy of Mutualism." American Journal of Sociology 118, no. 3 (2012): 635-675.

Greve, H. R. and H. Rao. "History and the present: Institutional legacies in communities of organizations". Research in Organizational Behavior, 34 (2014): 27-41.

Griffin, L.J., 'Temporality, Events, and Explanation in Historical Sociology An Introduction'. Sociological methods \& research 20, no. 4 (1992): 403-27.

Guillet, E.C. Pioneer inns and taverns. Vol. Vol 1, Combined Edition. Toronto: The Ontario Publishing Company, 1954.

Gusfield, J., 'Passage to play: rituals of drinking time in American society'. Constructive drinking (1987): 73-90.

Hallowell, G.A. Prohibition in Ontario, 1919-1923. Ottawa: Ontario Historical Society, 1972. Hannan, M.T. and J. Freeman. Organizational Ecology. New York: Oxford University Press, 1989. Hatch, M. J. and M. Schultz. The Dynamics of Organizational Identity. Human Relations 55, no. 8 (2002): 989-1018.

Hills, Shilo, Maxim Voronov and C. R. Bob Hinings. "Putting New Wine in Old Bottles: Utilizing Rhetorical History to Overcome Stigma Associated with a Previously Dominant Logic." Research in the Sociology of Organizations 39, (2013): 99-137.

'His Mug Runneth Over', Chap., In Financial Post Magazine, 20-221993.

Hsu, G. and M.T. Hannan, 'Identities, genres, and organizational forms'. Organization Science 16, no. 5 (2005): 474-90.

Hughes, D., 'The brewing industry in early Australia', Chap., In The dynamics of the international brewing industry since 1800, edited by Wilson, R.G. and T.R. Gourvish, 213-28. New York:

Routledge, 1998.

Kavafian, J.H. and L. Boily. Beverage and Tobacco Guidebook. Montreal: Levesque, Beaubien, Geoffrion, 1995.

Kerr, K.A., 'The American Brewing Industry, 1865-1920', Chap., In The dynamics of the international brewing industry since 1800, edited by Wilson, R.G. and T.R. Gourvish, 176-92. New York:

Routledge, 1998.

Kodeih, F. and R. Greenwood, 'Responding to Institutional Complexity: The Role of Identity'. Organization Studies 35, no. 1 (2014): 7-39, doi:10.1177/0170840613495333.

Kroezen, J.J. and P. Heugens, 'Organizational identity formation: Processes of identity imprinting and enactment in the Dutch microbrewing land-scape', Chap., In Constructing identity in and around organizations, edited by Schultz, M., S. Maguire, A. Langley and H. Tsoukas, 89-127. Oxford: Oxford University Press, 2012. 
Lamertz, K., P.P.M.A.R. Heugens, and L. Calmet, 'The Configuration of Organizational Images Among Firms in the Canadian Beer Brewing Industry*'. Journal of Management Studies 42, no. 4 (2005): 817-43.

MacKinnon, J. The Great Lakes Beer Guide. Erin: Boston Mills Press, 1997. Maguire, S. and C. Hardy, 'Discourse and Deinstitutionalization: the Decline of DDT'. Academy of Management Journal 52, no. 1 (2009): 148-78, doi:10.5465/amj.2009.36461993. McBurney, M. and M. Byers. Tavern in the town: Early inns and taverns of Ontario: University of Toronto Press, 1987.

McCalla, D. Consumption Stories: Customer purchases of alcohol at an upper canadian country store in 1808-1809 and 1828-1829. Quebec: Centre Interuniversitaire d'etudes Quebecoises, 1999. McKendrick, D. G., and M. T. Hannan. "Oppositional Identities and Resource Partitioning: Distillery Ownership in Scotch Whisky, 1826-2009." Organization Science 25, no. 4 (2014): 1272-1286. McLeod, Alan and Jordan St John. Ontario Beer: A Heady History of Brewing from the Great Lakes to the Hudson Bay. Charleston: The History Press, 2014.

Nag, R., K.G. Corley, and D.A. Gioia, 'The intersection of organizational identity, knowledge, and practice: Attempting strategic change via knowledge grafting'. Academy of Management Journal 50, no. 4 (2007): 821-47.

North, Douglas C. "Institutions, Institutional Change and Economic Performance." In The New Institutionalism in Organizational Analysis, edited by Walter W. Powell and Paul J. DiMaggio, vii, 478 p. Chicago: University of Chicago Press, 1991.

Oliver, C., 'The institutional embeddedness of economic activity', Chap., In Advances in Strategic Management, edited by Baum, J.A.C. and J.E. Dutton, 163-86. Greenwich: JAI Press, 1996.

Palmer, J., 'Brewing Storm'. Barron's 76 (1996): 44.

Papoff, L., 'Last call for a crafty rebel', Chap., In Profit: The Magazine for Canadian Entrepreneurs, 31-331998.

Patvardhan, S., D. Gioia, and A. Hamilton, 'Weathering a Metalevel Identity Crisis: Forging a Coherent Collective Identity for an Emerging Field'. Academy of Management Journal (2014), doi:10.5465/amj.2012.1049.

Pedersen, J.S. and F. Dobbin, 'In search of identity and legitimation bridging organizational culture and neoinstitutionalism'. American Behavioral Scientist 49, no. 7 (2006): 897-907.

Popham, R.E. and W. Schmidt. Statistics of alcohol use and alcoholism in Canada, 1871-1956. Toronto: University of Toronto Press, 1958.

Porac, J.F., H. Thomas, and C. Baden - Fuller, 'Competitive Groups as Cognitive Communities: The Case of Scottish Knitwear Manufacturers'. Journal of Management Studies 26, no. 4 (1989): 397-416. Powell, W.W., 'On the nature of institutional embeddedness: Labels vs explanation', Chap., In Advances in Strategic Management, edited by Baum, J.A.C. and J.E. Dutton, 293-300. Greenwich: JAI Press, 1996.

Pratt, M.G., 'Disentangling collective identities', Chap., In Research on managing groups and teams, edited by Polzer, J.T., E. Mannix and M.A. Neale, 161-88. Greenwich: JAI Press, 2003.

Rao, H., 'The Social Construction of Reputation: Certification Contests, Legitimation, and the Survival of Organizations in the American Automobile Industry: 1895-1912'. Strategic Management Journal 15, no. S1 (1994): 29-44, doi:10.1002/smj.4250150904.

Rao, H., P. Monin, and R. Durand, 'Institutional Change in Toque Ville: Nouvelle Cuisine as an Identity Movement in French Gastronomy'. American Journal of Sociology 108, no. 4 (2003): 795-843, doi:10.1086/367917.

Ravasi, D. and M. Schultz, 'Responding to organizational identity threats: Exploring the role of 
organizational culture'. Academy of Management Journal 49, no. 3 (2006): 433-58.

Raynard, M., M. Lounsbury, and R. Greenwood, 'Legacies of Logics: Sources of Community Variation in CSR Implementation in China', Chap., In Institutional Logics in Action, Part A, edited by Lounsbury, M. and E. Boxenbaum, 243-76: Emerald Group Publishing Limited, 2013. Report of the Royal Commission on the Liquor Traffic in Canada. Ottawa: Dominion, 1895. Ronnenberg, H.W., 'The American brewing industry since 1920', Chap., In The dynamics of the international brewing industry since 1800, edited by Wilson, R.G. and T.R. Gourvish, 193-212. New York: Routledge, 1998.

Rubtsova, A., R. DeJordy, M. A. Glynn and M. Zald. "The Social Construction of Causality: The Effects of Institutional Myths on Financial Regulation." 30, 201-244, 2010.

Schneiberg, M., 'What's on the path? Path dependence, organizational diversity and the problem of institutional change in the US economy, 1900-1950'. Socio-Economic Review 5, no. 1 (2007): 47-80. Schultz, M., and T. Hernes. A Temporal Perspective on Organizational Identity. Organization Science 24, no. 1 (2013): 1-21.

Scott, W.R. Institutions and organizations, Foundations for organizational science. Thousand Oaks: SAGE, 1995.

Shea, A.A. Vision in Action. Toronto: Canadian Breweries Limited, 1955.

Smart, R.G. and A.C. Ogborne. Northern Spirits: Drinking in Canada, Then and Now: Addiction Research Foundation, 1986.

Suddaby, R., W.M. Foster and C. Quinn-Trank. "Rhetorical History as a Source of Competitive Advantage." In Advances in Strategic Management: The Globalization of Strategy Research, edited by Joel A. C. Baum and Joseph Lampel, 147-173. Bingley: Emerald, 2010.

Swaminathan, A., 'Entry into new market segments in mature industries: Endogenous and exogenous segmentation in the US brewing industry'. Strategic Management Journal 19 (1998): 389-404.

'The Canadian Beer Index'. http://realbeer.com/canada/.

Van de Ven, Andrew H., and Marshall Scott Poole. "Methods for Studying Innovation Development in the Minnesota Innovation Research Program." Organization Science 1, no. 3 (1990): 313-35.

Van Munching, P. Beer Blast. Toronto: Random House, 1997.

Wade, J.B., A. Swaminathan, and M.S. Saxon, 'Normative and resource flow consequences of local regulations in the American brewing industry, 1845-1918'. Administrative Science Quarterly (1998): 905-35.

Warsh, C.K., 'John Barleycorn Must Die: An Introduction to the Social History of Alcohol'. Drink in Canada: Historical Essays (1993): 3-26.

Weber, K. and M.T. Dacin, 'The Cultural Construction of Organizational Life: Introduction to the Special Issue'. Organization Science 22, no. 2 (2011): 287-98, doi:doi:10.1287/orsc.1100.0632.

Williamson, O.E., 'The economics of organization: The transaction cost approach'. American Journal of Sociology (1981): 548-77.

Wry, T., M. Lounsbury, and M.A. Glynn, 'Legitimating nascent collective identities: Coordinating cultural entrepreneurship'. Organization Science 22, no. 2 (2011): 449-63.

Zietsma, C., and B. McKnight. "Building the Iron Cage: Institutional Creation Work in the Context of Competing Proto-Institutions.". Chap. 6 In Institutional Work: Actors and Agency in Institutional Studies of Organizations, edited by Thomas B. Lawrence, Roy Suddaby and Bernard Leca. 143-77. Cambridge: Cambridge University Press, 2009. 
${ }^{1}$ e.g., Albert and Whetten, 'Organizational identity'; DiMaggio and Powell, 'The iron cage revisited'; Weber and Dacin, 'The Cultural Construction of Organizational Life'.

${ }^{2}$ Ravasi and Schultz, 'Responding to organizational identity threats'.

${ }^{3}$ Glynn and Abzug, 'Institutionalizing Identity'.

${ }^{4}$ Glynn, 'Beyond constraint: How institutions enable identities'.

${ }^{5}$ Lamertz et al., 'The Configuration of Organizational Images'; Glynn and Abzug, 'Institutionalizing Identity'.

${ }^{6}$ Carroll and Swaminathan, 'Why the Microbrewery Movement?'.

${ }^{7}$ Pratt, 'Disentangling collective identities'.

${ }^{8}$ Patvardhan et al., 'Weathering a Metalevel Identity Crisis'.

${ }^{9}$ North, 'Institutions, institutional change and economic performance'; Hannan and Freeman, 'Organizational ecology'.

${ }^{10}$ Dobrev 'Revisiting organizational legitimation'; Dowell \& David, 'Effects of ancestral populations'; Greve \& Rao, 'Echoes of the Past'; Greve and Rao 'History and the present'; Raynard et al., 'Legacies of Logics'; Schneiberg, 'What's on the path?'; Zietsma \& McKnight, 'Building the Iron Cage'.

${ }^{11}$ Zietsma \& McKnight, 'Building the iron cage'.

${ }^{12}$ Dowell \& David, 'Effects of ancestral populations'.

${ }^{13}$ Rubtsova et al., 'The social construction of causality'.

${ }^{14}$ Schneiberg, 'What's on the path?'.

${ }^{15}$ Raynard et al., 'Legacies of Logics'.

${ }^{16}$ Albert and Whetten, 'Organizational identity'.

${ }^{17}$ Pedersen and Dobbin, 'In search of identity and legitimation'; Weber and Dacin, 'The Cultural Construction of Organizational Life'.

${ }^{18}$ Brickson, 'Organizational identity orientation'; Glynn and Abzug, 'Institutionalizing Identity'.

${ }^{19}$ Glynn, 'Beyond constraint: How institutions enable identities'; Kodeih and Greenwood, 'Responding to Institutional Complexity'.

${ }^{20} \mathrm{Hsu}$ and Hannan, 'Identities, genres, and organizational forms'.

${ }^{21}$ Glynn and Abzug, 'Institutionalizing Identity'.

${ }^{22}$ Wry et al., 'Legitimating nascent collective identities'.

${ }^{23} \mathrm{Nag}$ et al., 'The intersection of organizational identity, knowledge, and practice'; Glynn, 'When cymbals become symbols'.

${ }^{24}$ Czarniawska and Wolff, 'Constructing New Identities'.

${ }^{25}$ Brickson, 'Organizational identity orientation'.

${ }^{26}$ Baron, 'Employing identities in organizational ecology'.

${ }^{27}$ Brown and Humphreys, 'Organizational identity and place'.

${ }^{28}$ Carroll and Swaminathan, 'Why the Microbrewery Movement?'.

${ }^{29}$ Friedland and Alford, 'Bringing Society Back In'.

${ }^{30}$ Elsbach and Kramer, 'Members' responses to organizational identity threats'.

${ }^{31}$ Glynn, 'When cymbals become symbols'; Kroezen and Heugens, 'Organizational identity formation'.

${ }^{32}$ Wry et al., 'Legitimating nascent collective identities'.

33 Ibid.

${ }^{34}$ Carroll and Swaminathan, 'Why the Microbrewery Movement?'; McKendrick and Hannan, 'Oppositional Identities and Resource Partitioning'.

${ }^{35}$ Glynn 'Beyond constraint: How institutions enable identities'; Pedersen and Dobbin, 'In search of identity and legitimation'. 
${ }^{36}$ Hatch and Schultz, 'The Dynamics of Organizational Identity'; Schultz and Hernes, 'A Temporal Perspective on Organizational Identity'.

${ }^{37}$ Greve \& Rao, 'Echoes of the Past'; Greve and Rao 'History and the present'.

${ }^{38}$ Dobrev 'Revisiting organizational legitimation'; Schneiberg, 'What's on the path?'.

${ }^{39}$ Schneiberg, 'What's on the path?', 49.

${ }^{40}$ Rao, Monin and Durand, "Institutional Change in Toque Ville'.

${ }^{41}$ Berger and Luckmann, 'The social construction of reality'.

${ }^{42}$ Griffin, 'Temporality, Events, and Explanation'.

43 Abrams, 'History, sociology, historical sociology'; Griffin, 'Temporality, Events, and Explanation'; Czarniawska and Wolff, 'Constructing New Identities'.

${ }^{44}$ Maguire and Hardy, 'Discourse and Deinstitutionalization'.

${ }^{45}$ Abrams, 'History, sociology, historical sociology'.

${ }^{46}$ Czarniawska and Wolff, 'Constructing New Identities'.

${ }^{47}$ Abrams, 'History, sociology, historical sociology'; Van de Ven and Mars, 'Methods for Studying Innovation'.

${ }^{48}$ Scott, 'Institutions and organizations', 56.

${ }^{49}$ Brewers Association of Canada, 'Brewing in Canada', 92.

${ }^{50}$ Smart and Ogborne, 'Northern Spirits'.

${ }^{51}$ Gusfield, 'Passage to play'; Warsh, 'John Barleycorn Must Die'.

52 Baron, 'Brewed in America'; Hughes, 'The brewing industry in early Australia'.

53 Bowering, 'The Art and Mystery'.

${ }^{54}$ Carstairs, '"Roots" Nationalism'; Baron, 'Brewed in America'; Butcher, 'Ale \& Beer'; MacKinnon, 'The Great Lakes Beer Guide'; Bowering, 'The Art and Mystery'.

${ }^{55}$ Bowering, 'The Art and Mystery'; Hughes, 'The brewing industry in early Australia'.

${ }^{56}$ Bowering, 'The Art and Mystery'.

${ }^{57}$ Ibid.

${ }^{58}$ McBurney and Byers, 'Tavern in the town'; Warsh, 'John Barleycorn Must Die'.

${ }^{59}$ Guillet, 'Pioneer inns and taverns'; McBurney and Byers, 'Tavern in the town'; Smart and Ogborne, 'Northern Spirits'; Warsh, 'John Barleycorn Must Die'.

${ }^{60}$ Guillet, 'Pioneer inns and taverns'; McBurney and Byers, 'Tavern in the town'.

${ }^{61}$ Smart and Ogborne, 'Northern Spirits'.

${ }^{62}$ Bowering, 'The Art and Mystery'.

${ }^{63}$ Bowering, 'The Art and Mystery'; MacKinnon, 'The Great Lakes Beer Guide'; Brewers Association of Canada, 'Brewing in Canada'.

${ }^{64}$ Bowering, 'The Art and Mystery'; Denison, 'The Barley and the Stream'; Butcher, 'Ale \& Beer'.

${ }^{65}$ Baron, 'Brewed in America'; Butcher, 'Ale \& Beer'; Bowering, 'The Art and Mystery'; Shea, 'Vision in Action'.

${ }^{66}$ Shea, 'Vision in Action'; Warsh, 'John Barleycorn Must Die'.

${ }^{67} \mathrm{McC}$ alla, 'Consumption Stories'.

${ }^{68}$ Bowering, 'The Art and Mystery'; McBurney and Byers, 'Tavern in the town'.

${ }^{69}$ Bowering, 'The Art and Mystery'.

${ }^{70}$ Warsh, 'John Barleycorn Must Die'.

${ }^{71}$ Dominion Brewers Association, 'Facts on the brewing industry in Canada'.

72 Bowering, 'The Art and Mystery'; Smart and Ogborne, 'Northern Spirits'; Warsh, 'John Barleycorn Must Die'. 
${ }^{73}$ McBurney and Byers, 'Tavern in the town'; Warsh, 'John Barleycorn Must Die'.

${ }^{74}$ Smart and Ogborne, 'Northern Spirits'.

${ }^{75}$ Smart and Ogborne, 'Northern Spirits'; Warsh, 'John Barleycorn Must Die'.

${ }^{76}$ Guillet, 'Pioneer inns and taverns', 159.

${ }^{77}$ Ibid., 176.

${ }^{78}$ Brewers Association of Canada, 'Brewing in Canada'; Bowering, 'The Art and Mystery'.

${ }^{79}$ Popham and Schmidt, 'Statistics of alcohol'.

${ }^{80}$ Ibid.

81 'Report of the Royal Commission'.

${ }^{82}$ Ibid.

${ }^{83}$ Bowering, 'The Art and Mystery'; Baron, 'Brewed in America'; Shea, 'Vision in Action'.

${ }^{84}$ Gordon, 'Industry determinants of organizational culture'.

${ }^{85}$ Bowering, 'The Art and Mystery'; Denison, 'The Barley and the Stream'; Brewers Association of Canada, 'Brewing in Canada'.

${ }^{86}$ Bowering, 'The Art and Mystery'.

87 'Report of the Royal Commission'; Smart and Ogborne, 'Northern Spirits'.

${ }^{88}$ Smart and Ogborne, 'Northern Spirits'; Bowering, 'The Art and Mystery'; Warsh, 'John Barleycorn Must Die'.

${ }^{89}$ Wade et al., 'Normative and resource flow'.

${ }^{90}$ See Kerr, 'The American Brewing Industry, 1865-1920' and Wade et al., 'Normative and resource flow', for development in the US.

${ }^{91}$ Bowering, 'The Art and Mystery'.

${ }^{92}$ McLeod and John, 'Ontario Beer'.

${ }^{93}$ Dominion Brewers Association, 'Facts on the brewing industry in Canada'; Hallowell, 'Prohibition in Ontario, 1919-1923'; Smart and Ogborne, 'Northern Spirits'.

${ }^{94}$ Bowering, 'The Art and Mystery'; Dominion Brewers Association, 'Facts on the brewing industry in Canada'; Smart and Ogborne, 'Northern Spirits'; Shea, 'Vision in Action'.

${ }^{95}$ Hallowell, 'Prohibition in Ontario, 1919-1923'; Smart and Ogborne, 'Northern Spirits'.

${ }^{96}$ Dominion Brewers Association, 'Facts on the brewing industry in Canada'.

${ }^{97}$ Hallowell, 'Prohibition in Ontario, 1919-1923, 107-10'.

${ }^{98}$ Shea, 'Vision in Action'.

${ }^{99}$ Hallowell, 'Prohibition in Ontario, 1919-1923'.

${ }^{100}$ Williamson, 'The economics of organization'.

${ }^{101}$ Cavanagh and Clairmonte, 'Alcoholic beverages'; DiMaggio and Powell, 'The iron cage revisited'.

102 Beaumont, 'Stephen Beaumont's Great Canadian Beer Guide'; Brewers Association of Canada, 'Brewing in Canada'; Shea, 'Vision in Action'.

${ }^{103}$ Beaumont, 'Stephen Beaumont's Great Canadian Beer Guide'; Carroll and Swaminathan, 'Why the Microbrewery Movement?'; Van Munching, 'Beer Blast'; Ronnenberg, 'The American brewing industry since 1920'.

104 Denison, 'The Barley and the Stream'.

${ }^{105}$ MacKinnon, 'The Great Lakes Beer Guide'; Palmer, 'Brewing Storm'; Van Munching, 'Beer Blast'.

${ }^{106}$ Dominion Brewers Association, 'Facts on the brewing industry in Canada'.

${ }^{107}$ Bowering, 'The Art and Mystery'; Bowering, 'In Search of the Perfect Brew'; Shea, 'Vision in Action'.

${ }^{108}$ Shea, 'Vision in Action'. 
${ }^{109}$ Bowering, 'In Search of the Perfect Brew'; Shea, 'Vision in Action'.

${ }^{110}$ Dominion Brewers Association, 'Facts on the brewing industry in Canada'; Popham and Schmidt, 'Statistics of alcohol'.

${ }^{111}$ Dominion Brewers Association, 'Facts on the brewing industry in Canada'.

${ }^{112}$ Shea, 'Vision in Action'.

113 Ibid.

${ }^{114}$ DiMaggio and Powell, 'The iron cage revisited'.

115 Shea, 'Vision in Action'.

${ }^{116}$ Dominion Brewers Association, 'Facts on the brewing industry in Canada'.

${ }^{117}$ Bowering, 'The Art and Mystery'; Shea, 'Vision in Action'; Denison, 'The Barley and the Stream'; Beaumont, 'Stephen Beaumont's Great Canadian Beer Guide'; Canadian Breweries Ltd. was renamed Carling O'Keefe in 1971 and merged with Molson in 1989.

${ }^{118}$ Beaumont, 'Stephen Beaumont's Great Canadian Beer Guide'; Brewers Association of Canada, 'Brewing in Canada'; Cavanagh and Clairmonte, 'Alcoholic beverages'.

${ }^{119}$ Brewers Association of Canada, 'Annual Statistical Bulletin'; Dominion Brewers Association, 'Facts on the brewing industry in Canada'.

${ }^{120}$ Carroll and Swaminathan, 'Why the Microbrewery Movement?'.

${ }^{121}$ Denison, 'The Barley and the Stream', 340-45.

${ }^{122}$ Shea, 'Vision in Action', 94.

123 Ibid.

${ }^{124}$ Brewers Association of Canada, 'Brewing in Canada'; Dominion Brewers Association, 'Facts on the brewing industry in Canada'.

${ }^{125}$ Brewers Association of Canada, 'Brewing in Canada'; Cavanagh and Clairmonte, 'Alcoholic beverages'; Ronnenberg, 'The American brewing industry since 1920'; Shea, 'Vision in Action'.

${ }^{126}$ Carstairs, '"Roots" Nationalism'.

127 Shea, 'Vision in Action'.

128 Bowering, 'The Art and Mystery'; Denison, 'The Barley and the Stream'.

${ }^{129}$ Bowering, 'The Art and Mystery'; Shea, 'Vision in Action'; Denison, 'The Barley and the Stream'; Beaumont, 'Stephen Beaumont's Great Canadian Beer Guide'; Canadian Breweries Ltd. was renamed Carling O'Keefe in 1971 and merged with Molson in 1989.

${ }^{130}$ Beaumont, 'Stephen Beaumont's Great Canadian Beer Guide'.

${ }^{131}$ Beaumont, 'Stephen Beaumont's Great Canadian Beer Guide'; Canada, 'The Canadian Brewing Industry'; Carroll and Swaminathan, 'Why the Microbrewery Movement?'.

${ }^{132}$ Carroll and Swaminathan, 'Why the Microbrewery Movement?'.

${ }^{133}$ Brewers Association of Canada, 'Annual Statistical Bulletin'; Swaminathan, 'Entry into new market segments'.

${ }^{134}$ Beaumont, 'Stephen Beaumont's Great Canadian Beer Guide'.

135 Beaumont, 'Stephen Beaumont's Great Canadian Beer Guide'; 'The Canadian Beer Index'.

136 'Barnett's Experience Molson's Biggest Advantage'; Kavafian and Boily, 'Beverage and Tobacco Guidebook'; 'Beer Wars'.

${ }^{137}$ Beaumont, 'Stephen Beaumont's Great Canadian Beer Guide'.

${ }^{138}$ Beaumont, 'Stephen Beaumont's Great Canadian Beer Guide'; MacKinnon, 'The Great Lakes Beer Guide'.

${ }^{139}$ Eberts, 'Neolocalism and the Branding'.

${ }^{140}$ Bowering, 'In Search of the Perfect Brew'; Beaumont, 'The Great Canadian Beer Guide, Second 
Edition'; 'The Canadian Beer Index'.

${ }^{141}$ Green, 'Micro misery'.

${ }^{142}$ Carroll and Swaminathan, 'Why the Microbrewery Movement?'.

${ }^{143}$ Beaumont, 'Stephen Beaumont's Great Canadian Beer Guide'; MacKinnon, 'The Great Lakes Beer Guide'.

${ }^{144}$ Beaumont, 'Stephen Beaumont's Great Canadian Beer Guide'.

${ }^{145}$ Boisseau, 'The suds stud'.

${ }^{146}$ Beaumont, 'Raising a glass to brewpub culture'.

${ }^{147}$ Patvardhan et al., 'Weathering a Metalevel Identity Crisis'.

${ }^{148}$ Eberts, 'Neolocalism and the Branding'; Swaminathan, 'Entry into new market segments'.

${ }^{149}$ Dowell and David, 'Effects of ancestral populations'.

${ }^{150}$ Glynn, 'Beyond constraint'; Lamertz et al., 'The Configuration of Organizational Images'.

${ }^{151}$ Carroll and Swaminathan, 'Why the Microbrewery Movement?'; Wade et al., 'Normative and resource flow'.

${ }^{152}$ DiMaggio, 'Structural analysis of organizational fields'.

${ }^{153}$ Gordon, 'Industry determinants of organizational culture'.

${ }^{154}$ Abrahamson and Fombrun, 'Macrocultures: Determinants and consequences'; Chatman and Jehn, 'Assessing the relationship'.

${ }^{155}$ Fiol and Huff, 'Maps for managers'; Porac et al., 'Competitive Groups as Cognitive Communities'.

${ }^{156}$ Pratt, 'Disentangling collective identities', 173.

${ }^{157}$ Dobrev 'Revisiting organizational legitimation'; Dowell \& David, 'Effects of ancestral populations'; Greve \& Rao, 'Echoes of the Past'; Greve and Rao 'History and the present'; Raynard et al., 'Legacies of Logics'; Schneiberg, 'What's on the path?'; Zietsma \& McKnight, 'Building the Iron Cage'.

${ }^{158}$ Duymedjian and Rüling, 'Towards a Foundation of Bricolage'; Garud and Karnøe, 'Bricolage Versus Breakthrough'.

${ }^{159}$ Glynn, 'Beyond constraint'.

${ }^{160}$ Christiansen and Lounsbury, 'Strange Brew: Bridging Logics'.

${ }^{161}$ Oliver, 'The institutional embeddedness'; Powell, 'On the nature of institutional embeddedness'.

${ }^{162}$ Aldrich and Fiol, 'Fools rush in?'; Baum and Powell, 'Cultivating an institutional ecology'; Rao, 'The Social Construction of Reputation'.

${ }^{163}$ Baron, 'Employing identities in organizational ecology'; Lamertz et al., 'The Configuration of Organizational Images'.

${ }^{164}$ DiMaggio and Powell, 'Introduction'.

${ }^{165}$ Glynn and Navis, 'Categories, identities, and cultural classification'.

166 'His Mug Runneth Over', 22.

${ }^{167}$ Papoff, 'Last call for a crafty rebel'.

${ }^{168}$ Carroll and Swaminathan, 'Why the Microbrewery Movement?'.

${ }^{169}$ Lamertz et al., 'The Configuration of Organizational Images'.

${ }^{170}$ Beverland, 'Crafting Brand Authenticity'; Foster, 'History as social memory assets'; Hills et al., 'Putting new wine'; Suddaby et al., 'Rhetorical History as a Source'.

${ }_{172}^{17}$ Carroll and Swaminathan, 'Why the Microbrewery Movement?'.

${ }^{172}$ Wade et al., 'Normative and resource flow'.

${ }^{173}$ Carroll and Swaminathan, 'Why the Microbrewery Movement?'; Albert and Whetten, 'Organizational identity'.

${ }^{174}$ Schneiberg, 'What's on the path?'. 
${ }^{175}$ Oliver, 'The institutional embeddedness of economic activity', 177.

1

2

3

4

5

6

7

8

9

10

11

12

13

14

15

16

17

18

19

20

21

22

23

24

25

26

27

28

29

30

31

32

33

34

35

36

37

38

39

40

41

42

43

44

45

46

47

48

49

50

51

52

53

54

55

56

57

58

59

60 